\title{
Ecological and evolutionary approaches to managing honeybee disease
}

\author{
Berry J. Brosi ${ }^{1 \star}{ }^{\star}$, Keith S. Delaplane ${ }^{2}$, Michael Boots ${ }^{3}$ and Jacobus C. de Roode ${ }^{4 \star}$
}

\begin{abstract}
Honeybee declines are a serious threat to global agricultural security and productivity. Although multiple factors contribute to these declines, parasites are a key driver. Disease problems in honeybees have intensified in recent years, despite increasing attention to addressing them. Here we argue that we must focus on the principles of disease ecology and evolution to understand disease dynamics, assess the severity of disease threats, and control these threats via honeybee management. We cover the ecological context of honeybee disease, including both host and parasite factors driving current transmission dynamics, and then discuss evolutionary dynamics including how beekeeping management practices may drive selection for more virulent parasites. We then outline how ecological and evolutionary principles can guide disease mitigation in honeybees, including several practical management suggestions for addressing short- and long-term disease dynamics and consequences.
\end{abstract}

Oor ollinator declines are a major societal challenge. In particular, managed populations of the western honeybee are facing unprecedented declines ${ }^{1-4}$. In the US, the number of honeybee colonies has been reduced by half since 1940 (Fig. 1) in tandem with a large increase in the acreage of honeybee dependent crops ${ }^{5}$. Over the past several years, there have been annual losses of between 30 and $40 \%$ of all managed US honeybee colonies ${ }^{6}$, corresponding to over 1 million colonies lost per year ${ }^{5,7}$, alongside similar losses in Europe $^{8}$ (Fig. 1). These colony losses are detrimental to pollination services $^{9,10}$, threatening human health ${ }^{11}$ and hundreds of billions of dollars in agricultural value ${ }^{12}$. Honeybees are the most important managed pollinators worldwide ${ }^{13,14}$, contributing to the production of 39 of the 57 leading crops used for human consumption ${ }^{15}$. Many of these crops comprise the fruits, nuts, seeds and vegetables that provide the bulk of micronutrients to the human diet ${ }^{11,16,17}$.

Although many factors contribute to honeybee declines, such as pesticides and land-use change ${ }^{18,19}$, we focus here on parasites (Box 1). A wide range of parasites cause significant threats to honeybees, including viruses, bacteria, microsporidia, and arthropods $\mathrm{s}^{7,20-24}$ (Fig. 2 and Table 1). While colony losses have often been ascribed to colony collapse disorder-a syndrome associated with a loss of adult workers, a lack of dead or diseased bees in or near the colony, and the delayed invasion of nest scavengers-this disorder is hard to define, and its causes remain unclear. What is clear, however, is that many colony losses are due to parasites, whether alone, together, or in combination with other factors such as pesticides. In particular, the ectoparasitic mite Varroa destructor and the viruses it vectors are considered the primary cause of honeybee colony losses worldwide $\mathrm{e}^{1,25-31}$.

Why have honeybee disease management efforts had so little success? Early efforts (mid-2000s) took an 'outbreak mentality', trying to identify a single disorder driving declines ${ }^{32}$. More recent efforts have examined interactions between parasites ${ }^{24,26,33}$, or between parasites and other stressors ${ }^{18,34,35}$. Here, we argue that there is a need to better incorporate the principles of ecology and evolution to reveal fundamental causes of declines, predict factors that increase the severity of threats, and underpin knowledgebased solutions. We start by outlining ecological factors regulating honeybee disease, including host density and heterogeneity; host behaviour including ecological and social immunity; and community ecology. We then move to evolutionary processes, arguing that current beekeeping practices not only increase the prevalence and severity of disease outbreaks, but also thus promote natural selection for more virulent (harmful) parasites. We outline how an ecological and evolutionary framework can provide specific recommendations to mitigate disease threats and point out emerging research directions and challenges.

Our focus in this Review is on disease. Still, we underscore that to completely reverse honeybee declines other stressors such as pesticides, lack of forage, and land-use practices must be addressed ${ }^{18,34-37}$.

\section{Ecological considerations}

Host density is a key consideration for understanding the ecological dynamics of infectious disease.

Host density and infectious disease spread. The importance of population density for disease ecology is shown clearly in theoretical epidemiological models, which have been crucial to understanding infectious disease dynamics and control measures in humans, wildlife and agriculture ${ }^{38-42}$. These include SI and SIR models, based on the compartmentalization of each individual in the host population into susceptible (S), infected (I), or recovered and immune (R) classes (Box 2). Individual hosts move between compartments based on rates of transmission (from S to I) or recovery (from I to R). Despite the abstraction and simplicity of these models, they have been successful at reproducing disease dynamics in systems ranging from rabies in wild foxes $^{43}$ to Ebola in humans ${ }^{41}$, to foot and mouth disease in livestock ${ }^{42}$.

Host population density is a crucial determinant of transmission, parasite spread and epidemic size. Parasites are not only more likely to invade denser populations, but are also less likely to go extinct following initial epidemics ${ }^{44,45}$. The importance of host population density was first recognized by Kermack and McKendrick ${ }^{38}$ and verified by studies on measles in which larger cities showed greater and more frequent measles outbreaks and greater rates of endemism than smaller cities ${ }^{46,47}$. This increased risk is driven by higher densities of susceptible individuals, higher colonization rates by diseased individuals ${ }^{48}$ and higher contact rates ${ }^{49}$.

'Department of Environmental Sciences, Emory University, Atlanta, GA 30322, USA. ²Department of Entomology, University of Georgia, Athens, GA 30602, USA. 'ㄹepartment of Integrative Biology, University of California, Berkeley, CA 94720, USA. ${ }^{4}$ Department of Biology, Emory University, Atlanta, GA 30322, USA. Berry J. Brosi and Jacobus C. de Roode contributed equally to this work. *e-mail: bbrosi@emory.edu; jderood@emory.edu 

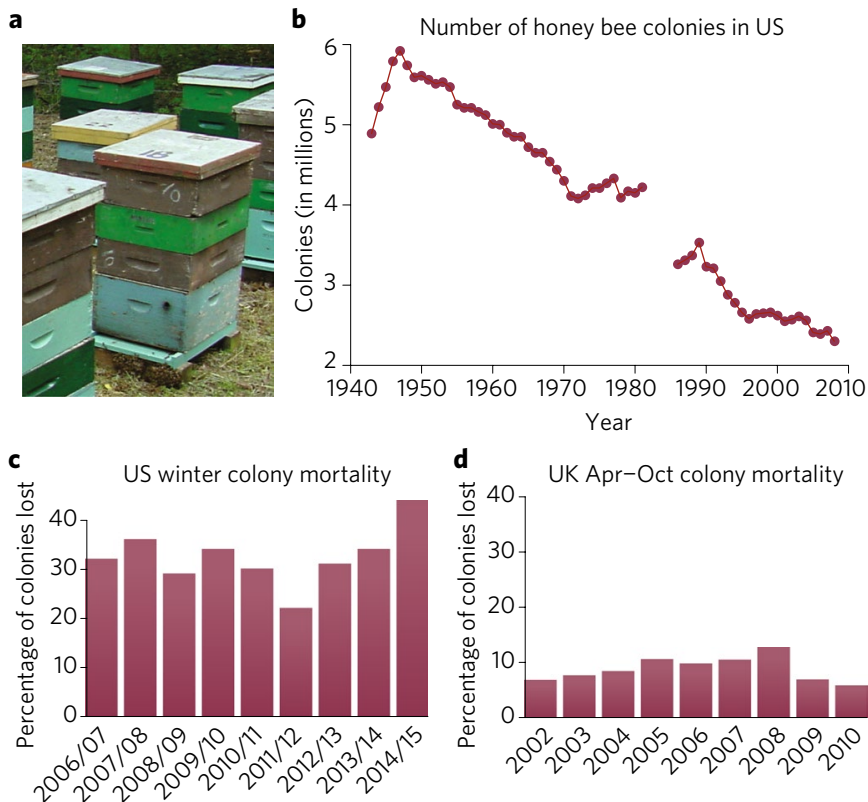

Fig. 1 | Honeybee colony losses. a, A typical managed honeybee colony. b, Colony numbers (in millions) in the United States between 1943 and $2016^{5}$. c, United States winter colony losses between 2006 and 2015,211. d, Breeding season colony losses in England and Wales between 2002 and $2010^{7}$. Data in c,d were obtained from graphs in their respective source papers ${ }^{5,7}$ using WebPlotDigitizer (http://arohatgi.info/ WebPlotDigitizer/app/). Photo credit: K.S.D.

High host density is thus a key factor that has contributed to increased parasite prevalence and incidence in honeybees. In modern beekeeping, this problem expresses at two levels-worker populations within colonies, and colony densities (apiaries) at a landscape scale. Larger colony populations are associated with more honey hoarding ${ }^{50}$, which has driven beekeeping interventions such as swarm prevention (discouraging colony reproductive fission), stimulatory feeding, and chemo-centric disease and parasite control to achieve unnaturally large forager populations and honey crops $^{51}$. As a result, while peak-season worker populations in healthy natural colonies in hollow trees are about $18,000^{52}$, reported peak-season populations in healthy managed colonies range from

\section{Box 1 | Parasites, pests and pathogens}

Different authors and scientific fields use different definitions of parasites, pests and pathogens. In the parasitological literature, parasites generally refer to protozoans and worms. Although epidemiologists may refer to protozoans, bacteria and viruses as pathogens, ecologists will often include bacteria and viruses in their broad definition of parasites. In the animal literature, the term 'pest' is often reserved for organisms that do not directly extract resources from hosts, but instead parasitize their habitats, such as nests and food sources.

In this Review we use the term 'parasite' to broadly refer to organisms that reduce the fitness of honeybees, either at the individual or colony level. Thus, parasites include any organism ranging from the deformed wing virus, which infects the haemolymph of bees and causes deformed wings, to Varroa destructor mites, which suck the blood of bee larvae, and small hive beetles, which parasitize the honey and pollen stores of honeybee colonies.
$20,000-52,000^{50,53,54}$. In addition, the average volume of natural tree hollows occupied by bees ranges from 15-80 litres ${ }^{55}$, while with US beekeeping equipment the standard 'Langstroth hive body'the basic module of a hive-contains a volume of 43 l. Beekeepers adjust module number as needed to accommodate seasonal fluxes in incoming honey, resulting in nest volumes ranging from 43-172 1. Although higher population sizes do not necessarily translate to higher within-colony densities, it is still likely that these practices support unnaturally high densities, and some specialty practices-such as the production of comb honey-call for radically dense worker populations ${ }^{56}$. The fact that simulated 'natural' colonies (approx. 10,000 bees kept year-round in single 431 hive bodies and left free to swarm) showed lower levels of Varroa mites and brood diseases compared with conventionally managed colonies (approx. 30,000 bees managed for swarm control) ${ }^{54}$ suggests that worker density within colony deserves more attention in the context of ecologically informed health management.

Moving from single colonies to apiaries (collections of multiple colonies in one location), beekeepers routinely maintain colonies at much greater densities in apiaries than occur in nature (Fig. 3a,b). While feral bee colonies occur at a density of around one per square kilometre ${ }^{57}$, industrial beekeeping operations may maintain thousands of colonies in a similar space. One study on Varroa compared an apiary of 12 bee colonies with 12 colonies scattered throughout the landscape, and found lower two-year colony survival in the apiary than in scattered colonies, as well as greater rates of drone drifting (that is, male bees entering non-home colonies) between colonies, consistent with greater Varroa transmission ${ }^{58}$. Betweencolony (horizontal) mite transmission has been independently supported $^{59-61}$, but the evidence is not always equivocal ${ }^{62}$. In order to better understand the importance of colony density in disease processes, more studies are necessary. For example, we know relatively little of the importance of dormancy in parasites (such as the bacterial causative agents of foulbrood) to transmission in heavily managed apiaries.

Despite the theoretical benefits of low host density, economic and cultural pressures have moved the beekeeping industry toward larger, denser apiaries. It is difficult to imagine significant departures from this paradigm unless cost-benefit analyses show that benefits of improved bee health significantly exceed costs from increased swarming and more scattered apiaries.

Demography and disease spread. Theoretical studies have shown that population demography crucially affects disease epidemics. Rapid demographic turnover, where new susceptible individuals are added to a population at high rates, leads to a greater probability of maintaining disease and sustaining epidemics over longer periods of time ${ }^{44,45}$. Modern day beekeepers do just that, by replacing succumbed colonies with new ones, thus artificially replenishing the population with susceptible hosts. This practice is facilitated by the use of 'package' bees (one queen with several pounds of workers) and 'nucleus' colonies (small colonies with a queen, $1-2$ pounds of bees, and $4-5$ combs of brood), hundreds of thousands of which are shipped annually to beekeepers for restocking dead colonies. This results in very different demographic dynamics relative to natural disease systems, where susceptibles are used up as an epidemic burns through a population.

Population heterogeneity. Theoretical and empirical studies have shown that genetically homogeneous populations of susceptible hosts are often prone to parasite invasion and rapid parasite spread. In contrast, in genetically variable populations, specialist parasites are less likely to spread, potentially resulting in less-severe disease in fewer individuals ${ }^{63}$. This is true at the species level as well, that is, more diverse communities often reduce the infection of susceptible host species $^{64,65}$. Similarly, intercropping and crop rotation in agriculture have been successful strategies for reducing the impacts of parasites ${ }^{66,67}$. 


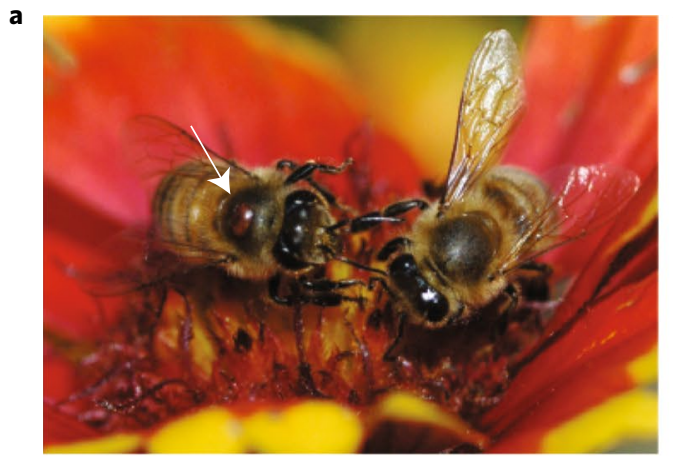

b
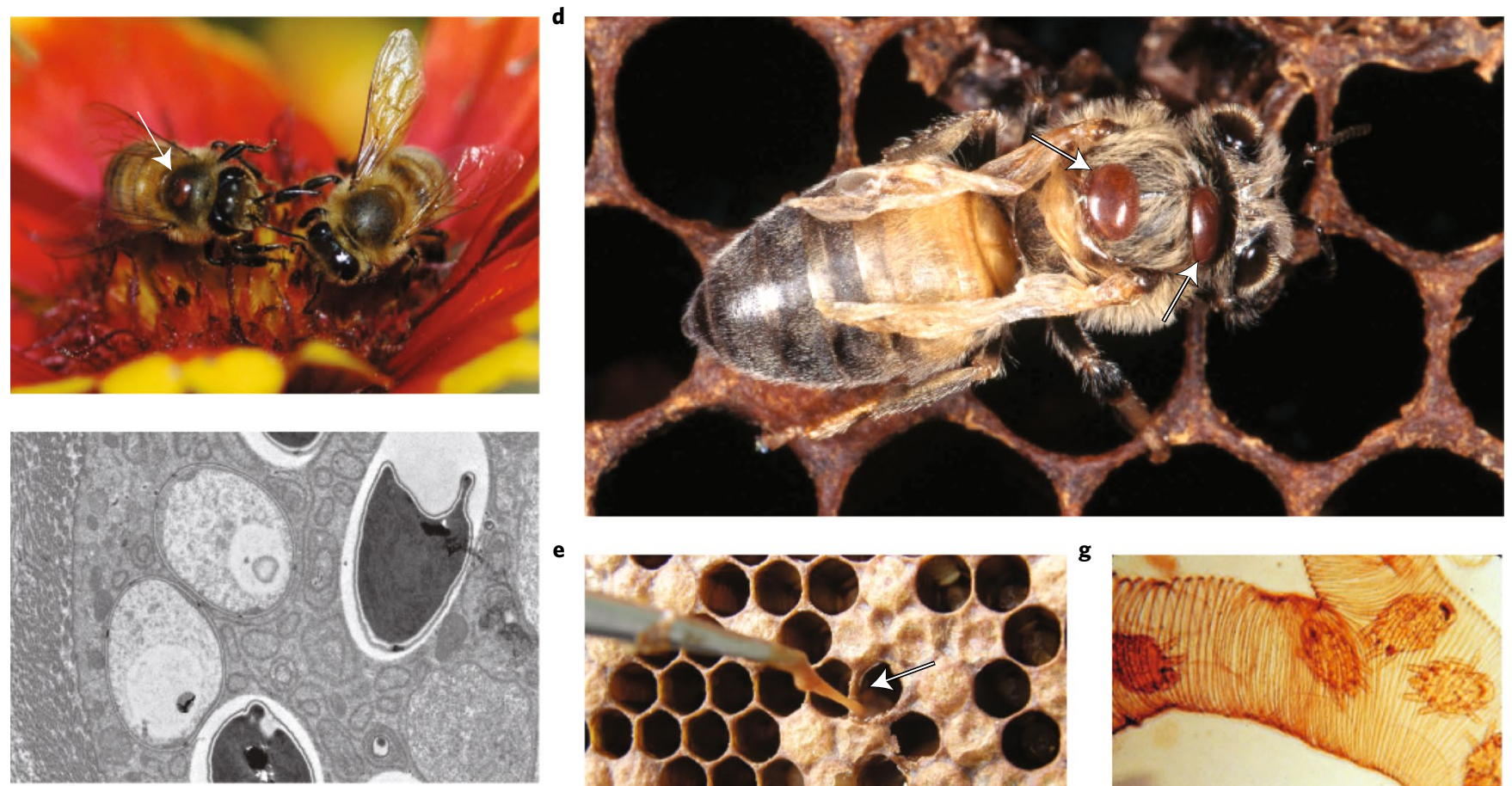

e

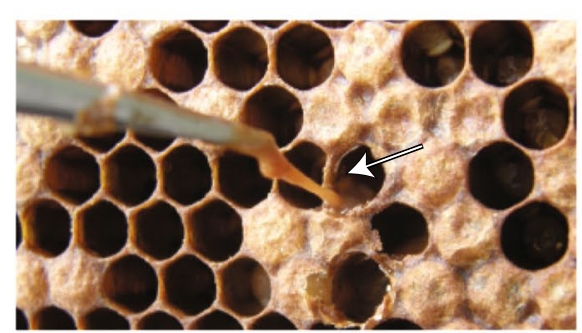

g
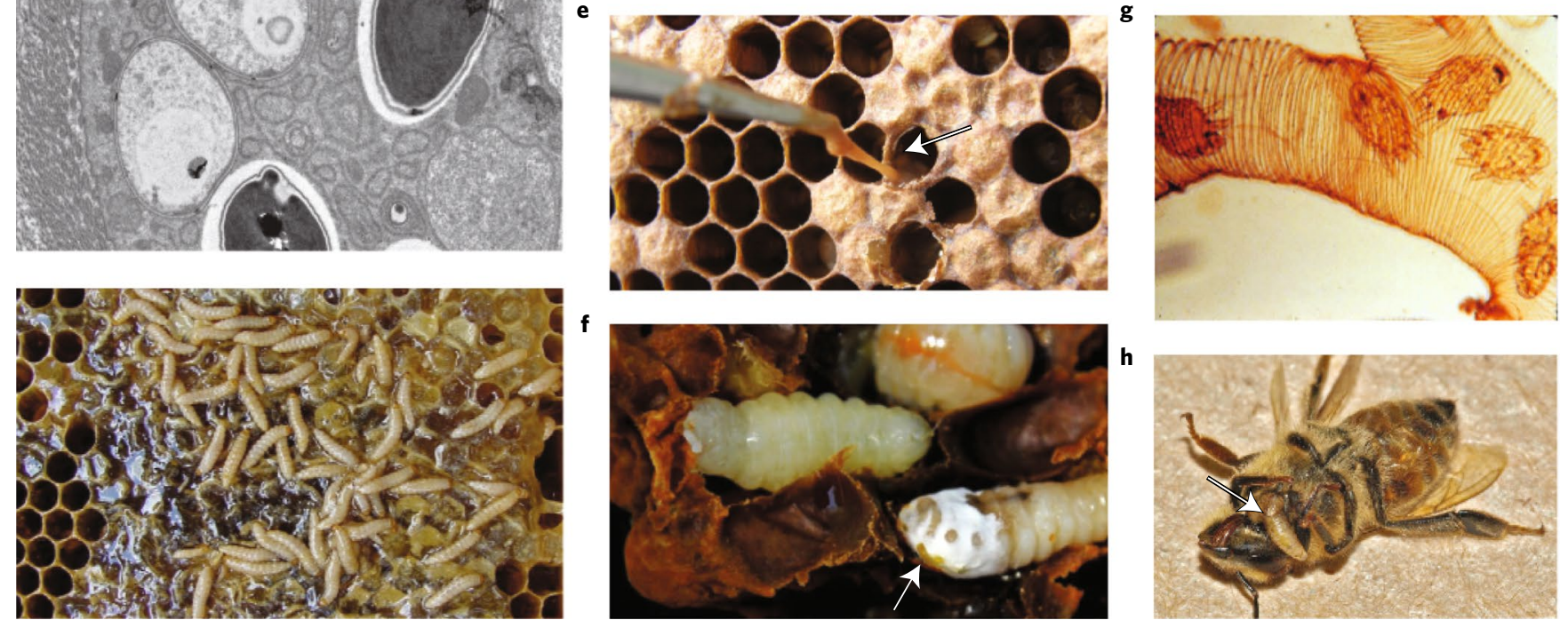

f
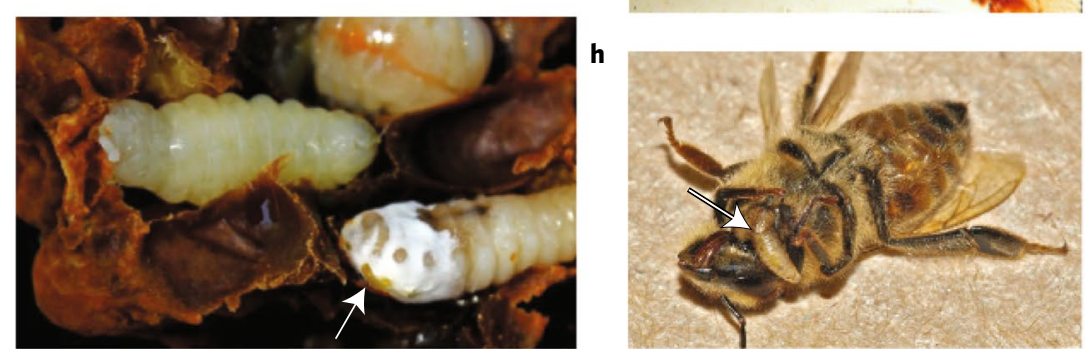

Fig. 2 | Parasites threatening honeybees. a, Varroa destructor mite (indicated with arrow) attached to a foraging worker bee. b, Spores of the microsporidian Nosema ceranae in a honeybee ventricular cell. c, Small hive beetle (Aethina tumida) larvae infesting a honeybee colony frame. d, A honeybee with deformed wings, caused by infection with deformed wing virus; the arrows point at Varroa mites, which vector and amplify the virus. e, A disintegrating honeybee pupa as a result of infection with the American foulbrood bacterium Paenibacillus larvae. f, Honeybee pupa infected with the fungus Ascosphaera apis, which causes chalkbrood disease. $\mathbf{g}$, Tracheal mites (Acarapis woodi) infesting honeybee tracheae. h, A parasitoid fly (Apocephalus borealis) larva (arrow) bursting out of an infected honeybee. Photo credits: Jennifer Berry (a); Mariano Higes (b); Jamie Ellis (c); Paul Kruse at KnackbockBlog (d); Western Australian Agriculture Authority (Department of Agriculture and Food, WA (e); Ron Snyder at the Bee Informed Partnership (f); USDA (g); John Hafernik (h).

Host heterogeneity is particularly important in honeybees, whose natural history is defined by eusociality. Even wild honeybee colonies naturally have high within-colony individual densities, in turn creating naturally high disease pressure ${ }^{68}$. In the context of host heterogeneity, this seems to be exacerbated by genotypic homogeneity: all of the individuals within a colony are siblings, borne from the same mother (the queen). But honeybees have an unusual mating system: queens are highly polyandrous, mating with an average of 12 males $^{69}$, allowing for relatively high within-colony genotypic diversity and a measure of resistance heterogeneity. Colonies headed by queens fertilized by greater numbers of drones can experience lower infestation rates with the American foulbrood bacterium Paenibacillus larvae, the chalkbrood fungus Ascosphaera apis, and the Varroa mite ${ }^{70-72}$. This is probably due to the presence of genetically resistant individuals within a colony. Thus, increasing genotypic variability within honeybee colonies could provide an effective way to control parasites.

Ecological and social immunity. Behaviour of individual animals is another ecological factor that can have dramatic effects on disease outcomes. Many animals modulate their ability to prevent, resist, or tolerate infections with behavioural changes including changes in diet. Many immune responses are energetically expensive, and there is an extensive literature demonstrating trade-offs between immune and other fitness-related functions under starvation or caloric restriction ${ }^{73-76}$. In beekeeping, ensuring sufficient food is a longstanding goal, and starvation is a common cause of colony loss ${ }^{77}$.

The theory of ecological immunology, however, gives us insights into the role of diet composition, as well as other behavioural elements, in fighting disease. Recent work shows that commercial protein supplements are associated with lower colony overwintering survival and higher parasite loads relative to pollen from a single plant source ${ }^{78}$. Dietary diversity also matters: more-diverse pollen diets are positively related to haemocyte concentration and phenoloxidase activity in honeybees, two aspects of insect immunity ${ }^{79}$.

A cornerstone of behavioural defence is 'self-medication', or the use of other species (typically plants and fungi and their associated microbiota) internally or externally, to protect against parasites ${ }^{80}$. For example, sheep and goats can reduce gastrointestinal nematode infection by selecting food with medicinal compounds, suggesting 


\section{Table 1 | Parasites of honeybees}

\begin{tabular}{|c|c|c|c|}
\hline Parasite & Parasite type & $\begin{array}{l}\text { Associated disease or } \\
\text { disorder }\end{array}$ & $\begin{array}{l}\text { Evidence for associations with disease/disorder and for the } \\
\text { establishment of parasite as etiological agent }\end{array}$ \\
\hline Varroa destructor & Mite & Varroosis & $\begin{array}{l}\text { Artificial inoculation of colonies led to colony losses }{ }^{104} \text {. Varroosis } \\
\text { stems from the synergistic effects of mite growth, honeybee immune } \\
\text { suppression and virus vectoring } 26 \text {, but statistical analysis showed that } \\
\text { growth of the mite alone contributes to colony collapse }{ }^{25} \text {. }\end{array}$ \\
\hline Acarapis woodi & Mite & Isle of Wight disease & $\begin{array}{l}\text { High levels of mite infestation were associated with high winter colony } \\
\text { mortality }{ }^{213} \text {. Artificial infection confirmed mortality of individual bees }{ }^{22} \text {. } \\
\text { Modeling suggested that mite infestation alone is enough to cause } \\
\text { colony mortality }{ }^{214} \text {, but a field study did not find negative colony effects } \\
\text { following experimental inoculation }{ }^{104} \text {. }\end{array}$ \\
\hline Nosema ceranae & Microsporidian & $\begin{array}{l}\text { Nosemosis type C, colony } \\
\text { collapse disorder }\end{array}$ & $\begin{array}{l}\text { Presence of } N \text {. ceranae was associated with smaller colony size } \mathrm{e}^{215} \\
\text { or colony collapse disorder in some studies }{ }^{33} \text { but not others }{ }^{27} \text {. } \\
\text { Experimental infection resulted in mortality of individual honeybees }{ }^{181} \text { as } \\
\text { well as colony collapse }{ }^{216} \text {. }\end{array}$ \\
\hline Nosema apis & Microsporidian & $\begin{array}{l}\text { Nosemosis type A, colony } \\
\text { collapse disorder }\end{array}$ & $\begin{array}{l}\text { N. apis was more prevalent in collapsing than non-collapsing colonies }{ }^{105} \text {. } \\
\text { Experimental infection resulted in parasite reproduction in bees, but no } \\
\text { obvious mortality was observed }{ }^{217} \text {. }\end{array}$ \\
\hline Ascosphaera apis & Fungus & Chalkbrood & $\begin{array}{l}\text { Experimental infection led to increased disease incidence within } \\
\text { colonies, reduced bee larva survival and reduced colony size } \mathrm{e}^{71,218} \text {. }\end{array}$ \\
\hline Paenibacillus larvae & Bacterium & American foulbrood & $\begin{array}{l}\text { Experimental inoculation led to bacterial infections and reduced colony } \\
\text { size }^{70} \text {. }\end{array}$ \\
\hline $\begin{array}{l}\text { Israeli acute paralysis virus } \\
\text { (IAPV) }\end{array}$ & Virus & $\begin{array}{l}\text { Colony collapse disorder, } \\
\text { paralysis }\end{array}$ & $\begin{array}{l}\text { IAPV was associated with colony collapse disorder in some studies }{ }^{32} \text {, } \\
\text { but not others } 27,105 \text {. Experimental injection resulted in paralysis and } \\
\text { death of individual bees }{ }^{219} \text {. }\end{array}$ \\
\hline $\begin{array}{l}\text { Deformed wing virus } \\
\text { (DWV) }\end{array}$ & Virus & $\begin{array}{l}\text { Varroosis, colony collapse } \\
\text { disorder }\end{array}$ & $\begin{array}{l}\text { DWV presence was associated with smaller colony size }{ }^{215} \text {, and the virus } \\
\text { was more prevalent in collapsing colonies }{ }^{105,220} \text {. Experimental feeding } \\
\text { of honeybee larvae by Varroa mites resulted in high replication of the } \\
\text { virus and experimental infection with DWV resulted in high bee larval } \\
\text { mortality }{ }^{26} \text {. }\end{array}$ \\
\hline Kashmir bee virus (KBV) & Virus & Colony collapse disorder & $\begin{array}{l}\text { KBV was more prevalent and occurred at higher titers in collapsed } \\
\text { colonies }^{27,105} . \text { A study in which KBV was quantified with the same } \\
\text { assay as ABPV and IAPV also showed higher prevalence in collapsing } \\
\text { colonies }^{220} \text {. }\end{array}$ \\
\hline $\begin{array}{l}\text { Black queen cell virus } \\
\text { (BQCV) }\end{array}$ & Virus & Colony collapse disorder & $\begin{array}{l}\text { BQCV presence was associated with smaller colony size } \mathrm{e}^{215} \text {, and was } \\
\text { more abundant in collapsing colonies }{ }^{105} \text {. Experimental infection with } \\
\text { BQCV did not result in increased worker or drone mortality }{ }^{221} \text {. }\end{array}$ \\
\hline $\begin{array}{l}\text { Acute bee paralysis virus } \\
\text { (ABPV) }\end{array}$ & Virus & Colony collapse disorder & $\begin{array}{l}\text { ABPV was more abundant in collapsing colonies }{ }^{105} \text {. Experimental } \\
\text { injection resulted in paralysis and death of individual bees }{ }^{219} \text {. }\end{array}$ \\
\hline $\begin{array}{l}\text { Chronic bee paralysis virus } \\
\text { (CBPV) }\end{array}$ & Virus & Chronic paralysis syndrome & Experimental infection resulted in viral replication and bee mortality ${ }^{100}$. \\
\hline Sacbrood virus (SBV) & Virus & Sacbrood & Experimental infection caused sacbrood in honeybee larvae ${ }^{222}$. \\
\hline Apis iridescent virus (AIV) & Virus & Colony collapse disorder & $\begin{array}{l}\text { AIV was associated with colony collapse disorder }{ }^{33} \text {, but this association } \\
\text { has been suggested to occur due to methodological error }{ }^{223} \text {. } \\
\text { Experimental infection with a closely related virus resulted in bee } \\
\text { mortality }{ }^{33} \text {. }\end{array}$ \\
\hline Apocephalus borealis & Phorid fly & Hive abandonment & $\begin{array}{l}\text { Parasitized bees leave their colonies at night and die shortly thereafter }{ }^{20} \text {, } \\
\text { similar to one of the symptoms of colony collapse disorder. Phorid fly } \\
\text { larvae often carry deformed wing virus and Nosema ceranae, suggesting } \\
\text { a potential role of this fly in transmission of these parasites. }\end{array}$ \\
\hline Aethina tumida & Nitidulid beetle & $\begin{array}{l}\text { Frame collapse and } \\
\text { swarming }\end{array}$ & $\begin{array}{l}\text { Small hive beetle larvae feed on honey and pollen. High reproduction can } \\
\text { lead to frame collapse, after which the bee colony often leaves the nest } \\
\text { by swarming } 224 \text {. }\end{array}$ \\
\hline
\end{tabular}

Following Koch's postulates ${ }^{88,212}$, many studies have established particular pathogens and parasites as the etiological agent of disease by demonstrating that infection reproduces the symptoms associated with the disease. We define parasites to include pathogens and parasites that exert their negative effects at either the level of the individual bee or colony.

that varied diets-as occur in nature but more rarely in managed systems - could simultaneously reduce disease and reduce selection for drug resistance (due to reduced drug use) ${ }^{81}$. This ability is not limited to vertebrates, and many insects utilize self-medication ${ }^{82}$. Honeybees infected with Nosema ceranae preferred sunflower honey over honeydew honey in dual-choice tests; sunflower honey had greater antimicrobial activity and reduced the numbers of $N$. ceranae spores in the bee gut ${ }^{83}$.

In honeybees, immune modulation and self-medication can relate not only to individual-level defences, but also to group- or 


\section{Box 2 | Infectious disease epidemiology}

Classic dynamical models of pathogen infections track host classes, such as susceptible and infected individuals and therefore ignore explicit within-host dynamics. Such compartment models may have many different host classes tracking recovered and immune or exposed individuals. A simple susceptible and infected SI model is shown as follows ${ }^{117,225}$ :

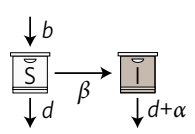

This model assumes that hosts are born at rate $b$, and die naturally at rate $d$. Infected hosts die at an additional death rate $\alpha$, often referred to as virulence. When susceptible and infected hosts make contact, susceptible hosts (S) turn into infected hosts (I) at rate $\beta$.

For a parasite that is driven by density-dependent transmission, the dynamics of this model can be captured by two coupled differential equations:

$$
\begin{gathered}
\frac{\mathrm{dS}}{\mathrm{d} t}=b(\mathrm{~S}+\mathrm{I})-\mathrm{dS}-\beta \mathrm{SI} \\
\frac{\mathrm{dI}}{\mathrm{d} t}=\beta \mathrm{SI}-(\alpha+d) \mathrm{I}
\end{gathered}
$$

One of the most useful quantities of compartment models is the basic reproductive ratio, $R_{0}$, which can be thought of as the number of new infected cases generated from one infection in a completely susceptible population. The equation for $R_{0}$ can be derived by setting $\mathrm{dI} / \mathrm{d} t>0$, to determine the condition that a parasite will spread in the host population.

$$
\begin{gathered}
\beta \mathrm{SI}-(\alpha+d) \mathrm{I}>0 \Longleftrightarrow \\
\frac{\beta \mathrm{S}}{(\alpha+d)}>1 \Longleftrightarrow \\
R_{0}=\frac{\beta \mathrm{S}}{(\alpha+d)}
\end{gathered}
$$

As is clear from this equation, when $R_{0}$ exceeds 1 , a parasite will be able to spread in a host population; when it is below 1 , it will tend to go extinct. Due to stochastic processes, parasites with $R_{0}$ values below 1 may still spread, but control efforts are focused on bringing $R_{0}$ below 1 to curb an epidemic, for example by vaccinating or culling hosts or reducing contact between host individuals. Moreover, as this equation makes clear, $R_{0}$ increases with greater transmission rate and greater host density. It is therefore predicted that parasites are more likely to invade, and less likely to go extinct, in host populations of greater density ${ }^{44}$.
With respect to honeybees, SI-type models may be used to study parasite spread between colonies, taking honeybee colonies as the susceptible and infected 'individuals'. Similar approaches have been used to model the spread of parasites in other agricultural practices, for example by taking farms or fields as the individual 'hosts' to model foot-and-mouth disease in livestock and rhizomania disease in sugar beet, respectively ${ }^{184,185}$. Considering colonies as the individual hosts allows for the study of arthropods, such as Varroa mites, which replicate within colonies, cause virulence at the colony level and transmit between colonies. Models can also be designed to study disease dynamics within colonies, or nested models can be created to link disease dynamics at the within- and between-colony levels ${ }^{205,226}$.

a

$$
\underset{\downarrow d}{\overrightarrow{\bar{S}}} \underset{\downarrow}{\stackrel{\vec{l}}{\bar{l} d}}
$$

b
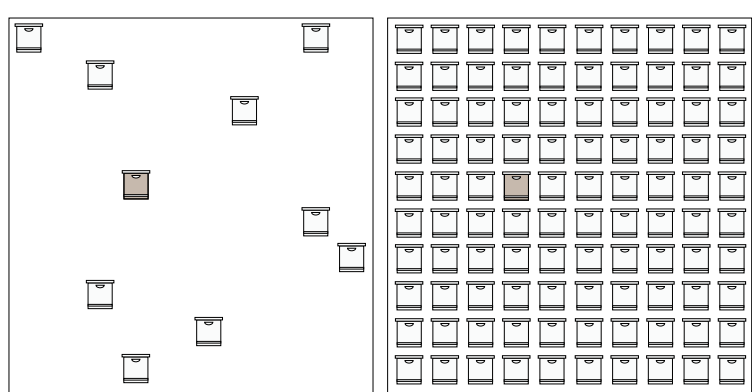

C
Low density

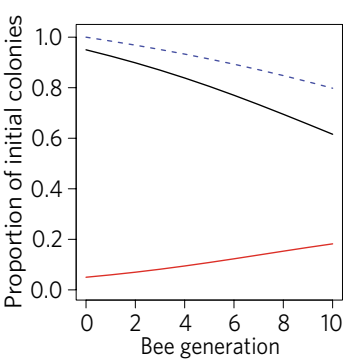

High density

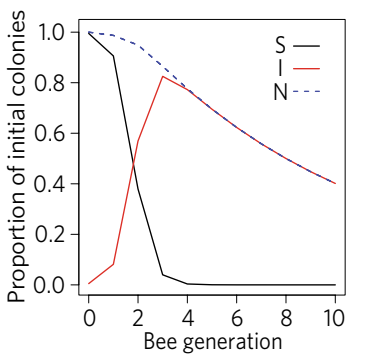

The importance of hive density on infectious disease spread. a, A simple disease dynamics model can be applied to honeybee parasites, in which colonies are either susceptible (S) or infected (I) with the parasite. Colonies die at a background rate $\mathbf{d}$ and become infected at the rate $\beta \mathrm{SI}$, in which $\beta$ is the transmission parameter. Infected colonies experience an additional mortality rate, $\alpha$, due to parasite infection. In this model, no new colonies are added, thus representing a situation in which disease dynamics are studied in apiaries with a fixed starting density of colonies. b. Graphical representation of colonies maintained at low density (left) and high density (right). c, Disease dynamics over 20 bee generations based on the model shown in panel $\mathbf{a}$, and with low density (20 colonies per apiary) or high density (200 colonies per apiary). Densities of susceptible (S), infected (I) and total (N) colonies are shown. At higher densities, parasites spread much more rapidly and cause greater proportional colony losses. (Parameter values used: $\mathrm{I}(0)=1, d=0.01, \beta=0.15, \alpha=0.1$.) colony-level defences, that is, 'social immunity'. Social immune mechanisms in both ants and honeybees include lining nest walls with plant-produced resins (called propolis by beekeepers), which reduces infection with fungal parasites and microorganisms $s^{84,85}$. Other mechanisms include removal of dead and diseased workers from colonies and 'social fever' or behaviourally induced increases in colony temperature to combat parasites ${ }^{86}$. We know little about the potentially wide range of social immune mechanisms in honeybees and how to support those mechanisms via management, but some studies have begun to address this topic. For example, 


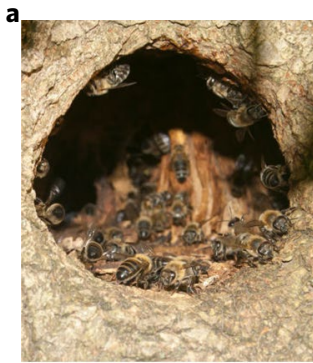

b
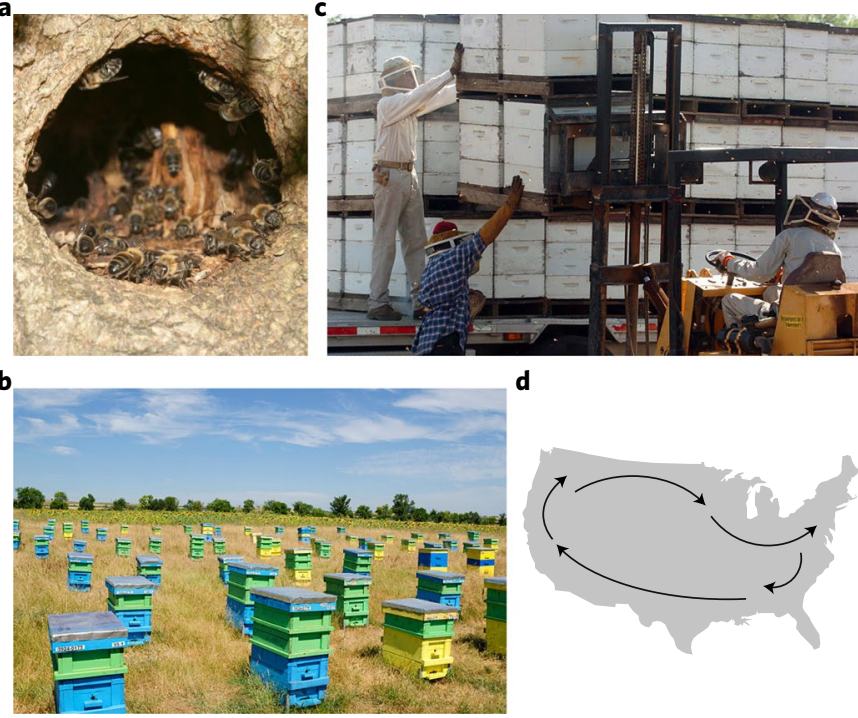

d

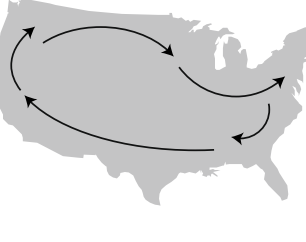

Fig. 3 | Beekeeping results in high bee densities and movement. a, Wild and feral honeybees, that is, those that have escaped management and are living outside of the realm of direct human influence, live in single colonies that are typically hyperdispersed in the landscape ${ }^{156}$. b. At the other extreme, intensively managed bees are kept in hyperconcentrated bee yards with hundreds or even thousands of colonies. c,d, Most of these operations are migratory, moving their colonies several thousand miles around states, countries and continents to provide pollination services for seasonal crops ${ }^{12}$. It is estimated that between one-half and two-thirds of all managed colonies in the US are moved to the almond orchards of California's Central Valley in late February and early March. Thus, transmission potential among these bees can be thought of as nearly global, since long-range movement is combined with high potential for contacting other bee colonies. Photo credits: Vitaliy Parts/Alamy Stock Photo (a); Dariya Angelova/Alamy Stock Photo (b); ZUMA Press, Inc./ Alamy Stock Photo (c).

beekeepers can maintain, rather than remove, propolis in colonies $^{84,85}$; and higher dietary pollen diversity increases the activity of glucose oxidase, an enzyme used to produce hydrogen peroxide for sterilizing food stores ${ }^{79}$.

As with many other insects, studies have shown that honeybees can pass on immunity to their offspring, a process called transgenerational immune priming. For example, the larvae of queens that had been challenged with Paenibacillus larvae, the bacterium causing American foulbrood, experienced lower mortality than larvae of queens that had not been challenged ${ }^{87}$. Such transgenerational immune priming could potentially be used to immunize bee colonies ${ }^{87}$.

Disease community ecology. Host-parasite interactions are often strongly influenced by the larger biological community ${ }^{88,89}$. Community ecology theory emphasizes two key interspecific interactions that are important for disease outcomes: (1) co-infections with other parasites; and (2) beneficial symbioses.

Co-infections with multiple parasites have important implications for parasite spread, disease severity and parasite evolution $^{90-94}$. Interactions between parasites or effects on virulence can express either positively or negatively, through immune suppression or within-host competition ${ }^{95-98}$. In honeybee pupae with mixed infections of Kashmir bee virus, sacbrood virus and black queen cell virus, inactivation of the first two viruses resulted in activation of the third, suggesting antagonistic interactions between viruses ${ }^{99}$. By contrast, co-inoculation of experimental bees with Nosema ceranae increased the infectivity of acute bee paralysis virus ${ }^{100}$, possibly due to honeybee immune suppression by N. ceranae $^{101}$. Beyond the individual level, co-infections are common at the colony level in honeybees, including different species of viruses, microsporidians, bacteria and mites ${ }^{7,32,102}$. Increasing numbers of the nest-invading small hive beetle Aethina tumida are associated with decreasing levels of Varroa ${ }^{103}$. In contrast, co-infection with Varroa and tracheal mites (Acarapis woodi) results in faster colony collapse than infestation with Varroa alone ${ }^{104}$. Colony collapse disorder is more often associated with multiple parasites than with single parasites ${ }^{27,105}$, and a study that inoculated bees with a mixture of four viruses showed elevated bee mortality ${ }^{24}$.

Varroa has been linked to honeybee declines around the world, and a major reason for this is the synergistic negative effects of Varroa and the viruses it vectors. Honeybee colony losses increased following the introduction of Varroa into the United States in the 1970s and $80 \mathrm{~s}^{106}$. Studies in Hawaii and New Zealand have demonstrated a link between Varroa invasion, increasing titres of viruses including deformed wing virus and Kashmir bee virus, and subsequent colony collapses ${ }^{3,107}$. Indeed, phylogenetic analyses of deformed wing virus indicate that the spread of Varroa around the world, caused by international bee trade, is responsible for the ongoing global epidemic of this virus ${ }^{108}$. Varroa is not only a vector of this virus, but enhances its infection and growth in bees by suppressing bee immunity ${ }^{109}$. Statistical analyses indicate that colony collapses in colonies infected with Varroa and deformed wing virus are not entirely due to viral infections, but also due to the damage done by the growth of Varroa itself ${ }^{25}$, thus further demonstrating the synergistic negative effects of co-infection with these parasites ${ }^{26}$.

Beyond co-infection, the presence of other organisms, such as beneficial symbionts, can provide protection against parasites ${ }^{110,111}$. In humans, intact gut microbial communities (together comprising the gut 'microbiome') provide protection against parasite infection, both through immunomodulation and direct interference between commensal gut bacteria and invading parasites ${ }^{112}$. Similarly, the honeybee gut harbours bacteria that are antagonistic to parasites ${ }^{113}$ such as Ascosphaera apis ${ }^{114}$. Such antagonistic interactions could provide tools for disease intervention. For example, inoculation of bee colonies with the bacterium Parasaccharibacter apium resulted in lower levels of Nosema ceranae infestation ${ }^{115}$.

\section{Evolutionary considerations}

Although ecological factors are crucial in determining the size, duration and severity of disease outbreaks, it is equally important to consider how evolution can shape disease outcomes. We focus here on the evolution of virulence, as it is probably a key driver of disease pressures in honeybees. We begin by discussing basic theory, and then discuss how host spatial structure and population heterogeneity affect virulence evolution; how imperfect treatments can affect virulence evolution; and the importance of cross-species transmission for virulence evolution.

Virulence-transmission trade-offs. Conventional wisdom on disease evolution held that given enough time, parasites would become benign to their host ${ }^{116}$. However, theoretical advancements over the past four decades have recognized that virulence is instead closely linked to parasite transmission ${ }^{39,117-119}$. Between-host transmission increases with increasing host exploitation rate but decreases with increasing clearance by the host as well as host death ${ }^{93,117,120-125}$. In the absence of constraints, parasites are expected to evolve an infinite transmission rate and zero virulence since this maximizes the infectious period. However, it is generally expected theoreticallyand often found empirically - that increasing parasite transmission rate comes at the cost of higher virulence, resulting in premature host death that reduces the infectious period ${ }^{125-132}$. Under these constraints, parasites are expected to evolve intermediate to high, but not infinite, levels of virulence. 
Beyond this basic 'trade-off model' of virulence evolution, studies have identified other regulators of virulence. For example, transmission opportunities are generally greater for parasites that are transmitted horizontally (between unrelated individuals) than for parasites transmitted vertically (from parent to offspring). As a result, horizontally transmitted parasites are expected to evolve higher virulence ${ }^{117,133,134}$. In addition, many hosts are co-infected with multiple strains of the same parasite species, and competition between these strains is expected to select for greater parasite virulence ${ }^{93,122,135}$. Increased horizontal transmission and within-host parasite competition are probably contributing to virulence evolution in honeybees, especially in managed systems. In modern beekeeping, the practice of replacing diseased with new susceptible colonies is also likely to have a major impact on the evolution of virulence. In this case, higher virulence increases the chance of the 'birth' of a new susceptible colony, in contrast to natural systems. This is clearly of benefit to the parasite, reducing the transmission cost of virulence and likely selecting for higher virulence. To determine how beekeeping results in virulence evolution by creating such novel demographics requires explicit theoretical models.

A necessary condition for virulence evolution is the existence of genetic variation in parasite virulence, which has been demonstrated in a number of honeybee parasites. Strains of the chalkbrood fungus Ascosphaera apis varied in larval mortality rates ${ }^{136}$, strains of deformed wing virus caused different mortality in adult bees $^{137}$, and several studies are consistent with genetic variation in Varroa mite virulence ${ }^{138-141}$. No robust studies have been carried out on virulence evolution, but basic theoretical assumptions are likely to be met. For example, bee colonies with higher numbers of Varroa mites are more likely to collapse $\mathrm{e}^{25,26,28,29,53,142}$, probably as a result of direct damage inflicted by haemolymph-feeding mites and viruses vectored by the mite $e^{25,28,143}$. Higher Varroa loads in colonies increase the transmission of mites to other colonies through natural processes such as drifting (bees enter the wrong hive by accident), robbing (bees enter other colonies to steal food), and beekeeping practices such as movement of brood frames between hives ${ }^{144}$. Thus, the honeybee-Varroa system meets the theoretical assumption that greater mite exploitation of a bee colony results in both greater virulence and between-colony transmission.

Spatial structure of transmission. Beyond transmission rates, the spatial patterns of transmission also play a key role in virulence evolution. Theoretical models show that when transmission occurs across long distances, parasites tend to evolve higher virulence than when it occurs locally (that is, between near neighbours) ${ }^{145-151}$. This is due in part to three interacting processes when transmission occurs locally. First, parasite infection results in a shielding effect by which infected individuals are surrounded by other infected or immune individuals who can no longer become infected. Second, highly virulent parasites drive themselves to extinction by killing all hosts in a local spatial cluster. These linked dynamics mean that highly virulent parasites truncate their own transmission via the extinction of nearby susceptible hosts ${ }^{151}$. Finally, genetic correlations also contribute to the lower virulence of locally transmitting parasites ${ }^{147,151-153}$ : when transmission occurs locally, parasites mostly compete with genetically related parasites for susceptible hosts, which is predicted to result in lower virulence.

Every year, American beekeepers generate conditions for increased virulence by routinely moving bees and brood (and their parasites) between colonies and by moving hundreds of thousands of colonies across the country for pollination contracts (Fig. 3c,d). Indirect evidence indicates that these practices have already resulted in more virulent parasites ${ }^{154}$. As one example, a Norwegian study found that colony losses tended to be higher among migratory than small-scale stationary beekeepers ${ }^{155}$. Moreover, in a cross-fostering study, Seeley ${ }^{156}$ inoculated feral bees (with a history of surviving
Varroa) and managed bees (with a history of succumbing to Varroa) with mites from managed colonies, and found no differences in bee resistance, thus suggesting that feral colony survival may be due to mite avirulence. This is particularly relevant since feral colonies are characterized by much more local transmission than managed bee colonies (Fig. 3).

Host population heterogeneity and virulence evolution. Most virulence evolution models assume homogeneity in host populations when in reality they vary in parasite susceptibility. Models that account for this variation have found that host heterogeneity can maintain parasite polymorphism ${ }^{157,158}$, and experimental studies have confirmed these predictions, for example in gypsy mothbaculovirus systems ${ }^{157}$. Host heterogeneity reduces specialization of parasites on any single host genotype, thereby reducing selection for a dominant virulent parasite genotype $\mathrm{e}^{159,160}$. Thus, in addition to providing direct benefits in terms of reducing disease progression (discussed above) $)^{70-72}$, genotypically diverse honeybee colonies are also less likely to select for highly virulent parasites.

Imperfect treatment and virulence evolution. It can seem paradoxical that selection for increased virulence can derive from actions taken to combat disease. As outlined above, parasites that reduce their own transmission by prematurely killing their hosts are not expected to be favoured by natural selection. However, theory has shown that disease treatments that act by reducing parasite growth-as opposed to preventing or curing infectionscan remove this cost of high virulence, thereby retaining virulent parasites in the population ${ }^{161-163}$. When infecting untreated hosts, such parasites grow faster and thereby cause greater levels of disease. Similarly, treatment based on increasing tolerance - the ability of a host to maintain fitness without reducing parasite burden-can select for highly virulent parasites ${ }^{164,165}$. Empirical evidence has been shown in Marek's disease, a viral ailment of poultry, in which the use of imperfect vaccines-which reduce viral growth but do not prevent infection-has coincided with increases in virulence ${ }^{166}$, and vaccinated chickens are able to transmit strains that are lethal to unvaccinated chickens ${ }^{167}$. Thus, in honeybees, the use of treatments such as acaricides that reduce parasite populations, but do not completely clear infestations, may similarly favour more virulent strains.

Cross-species transmission and virulence evolution. Some of the most devastating parasites are new to Apis mellifera. The original host of Varroa destructor is the Asian honeybee, Apis cerana ${ }^{168}$. Similarly, molecular studies have suggested that the microsporidian Nosema ceranae jumped species from the Asian honeybee to Apis mellifera in the past two decades ${ }^{21,169}$.

New host colonizations can have important consequences for host survival and parasite evolution ${ }^{170}$. Emerging parasites, such as SARS, HIV and Ebola viruses in humans, are often highly virulent. Such high virulence can arise through at least two processes. First, theoretical studies show that when parasites jump to a novel host species, they encounter a fully susceptible host population, which increases transmission opportunities and thereby selects for increased virulence ${ }^{127,171-174}$. Such increased transmission opportunities probably underlie the observed increases of virulence of Mycoplasma gallisepticum, which has recently emerged in house finch populations in North America ${ }^{175}$. Second, natural host-parasite interactions result in coevolutionary dynamics whereby hosts evolve tolerance or resistance as parasites evolve virulence ${ }^{165,176,177}$. Such highly evolved parasites may express much greater levels of virulence when they infect a novel host species without such resistance or tolerance mechanisms.

Both of these processes are likely important in emerging diseases of honeybees. For example, although Varroa destructor causes significant morbidity and mortality in A. mellifera, Apis cerana colonies 

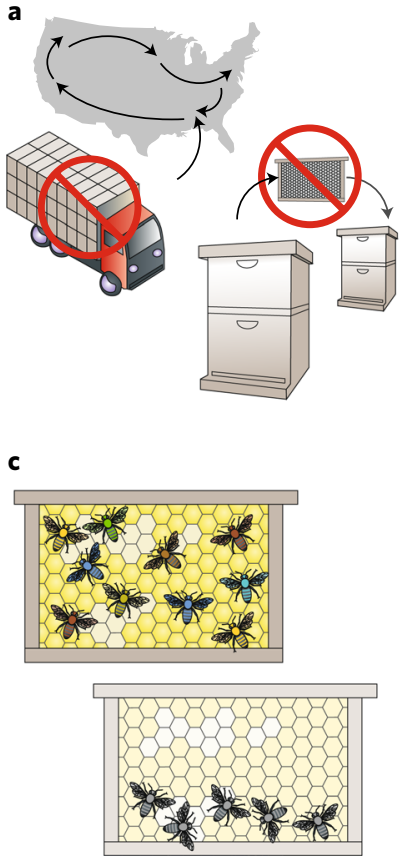

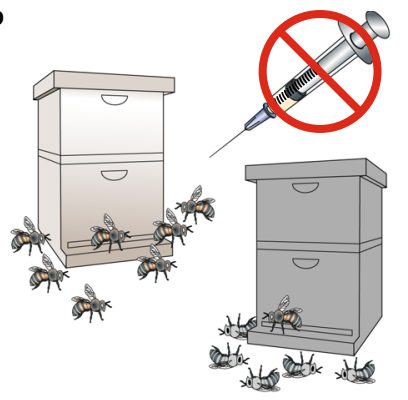

d

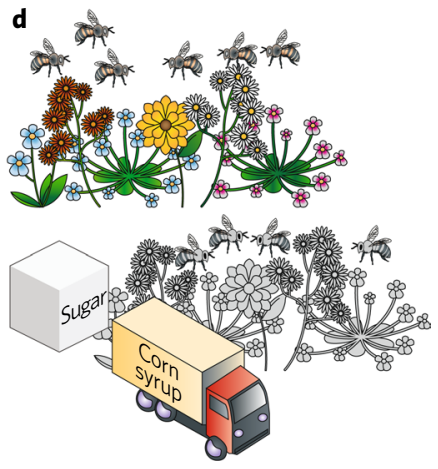

Fig. 4 | Management applications. a, Transmission reduction is a key management goal to reduce both ecological disease pressure and selection for greater parasite virulence; transmission reduction should occur at multiple scales, including the two shown here: between colonies within an apiary, and at continental scales. b. Promoting 'survivor stock', that is, allowing colonies with low parasite resistance to naturally die can increase the evolution of honeybee resistance. c, Increased colony-level genotypic diversity improves disease outcomes and supports general colony health, and may also reduce selection pressure for increased virulence evolution. d, Increased dietary diversity and reduced dependence on processed sugars can support better bee health and disease resistance, both for individual bees and for group-level defences.

are generally infested without measurable colony-level effects. This is partly because Varroa only infests drone (male) brood in A. cerana $a^{138,178-180}$, and $A$. cerana possesses behavioural defences to resist the mite, including removal of infected brood and social grooming. In A. mellifera colonies, Varroa is not limited to male brood, and its exploitation of worker brood (which comprise the vast majority of brood cells in a colony) allows for much greater population growth. In another example, the recent host shift of Nosema ceranae to A. mellifera has resulted in virulence in its new host; however, another microsporidian, Nosema apis, known to have infected A. mellifera for more than a hundred years, is much less virulent ${ }^{181}$, which supports the idea of attenuated virulence in the more coevolved relationships.

In natural populations, increases in adaptive virulence are expected to be transient ${ }^{127,171-174}$. Once a parasite has spread throughout the novel host population, the availability of susceptible hosts is reduced, selecting for lower parasite virulence. This process is supported by theory ${ }^{127,171-173}$ and empirical studies ${ }^{173,182}$. Within a few years after releasing a hypervirulent strain of myxoma virus to control rabbit populations in Australia, the virus evolved lower virulence, which maximized its between-host transmission ${ }^{183}$. Continued infection dynamics also select for more tolerant and resistant hosts, thereby reducing expressed virulence. This does not mean, however, that honeybee diseases will become less virulent in years to come. Instead, current beekeeping practices artificially sustain high transmission levels and also prevent the evolution of honeybee resistance or tolerance by employing artificial disease

control $^{57}$. Thus, without changes in current beekeeping practices, we should expect continued selection for highly virulent parasites.

\section{Applications}

The importance of ecological and evolutionary approaches to disease control is underscored in other agricultural systems. As described above, routine vaccination of poultry against Marek's disease has resulted in the evolution of virus hypervirulence ${ }^{167}$. Additional factors leading to high virulence in this virus include high chicken rearing densities and shorter cohort durations achieved by selective breeding ${ }^{166}$. Short cohort duration is expected to select for enhanced virulence because the cost of virulence (truncation of transmissible period) is less severe in short- versus long-lived hosts ${ }^{159}$. Similarly, high fish densities and fast maturation may have contributed to increased virulence evolution in aquaculture ${ }^{159}$.

We began this Review by discussing host density, a key variable in disease ecology. Host density was directly managed in the 2001 foot-and-mouth disease outbreak in the UK, where pre-emptive culling of farms nearby infected farms was effective in reducing the spread of the disease ${ }^{184}$. Similarly, in sugar beet systems, models show that crop removal in farms adjacent to farms with rhizomania disease could effectively reduce disease spread ${ }^{185}$. Both strategies essentially reduce the local density of susceptible 'individuals' (farms), thereby reducing parasite transmission.

We can apply lessons from disease ecology and evolution to improve parasite outcomes in honeybees. We distil these to six concrete management suggestions, which are specific to the biology of honeybees and the management context of beekeeping (Fig. 4). We then discuss the trade-offs between ecologically and evolutionarily minded strategies with other management goals.

Reducing disease transmission. Transmission reduction has potential benefits in terms of ecology (reducing the prevalence, severity and duration of outbreaks) and evolution (reducing selection for higher virulence). In honeybees, transmission occurs at multiple hierarchical scales, including within colonies; between colonies within apiaries; between apiaries; and within or between regions, countries, and continents. The modular and standardized feature of hive designs encourages transmission at all these scales. At the apiary level it is routine-even recommended-that beekeepers 'equalize' colony strength by moving combs of brood between colonies. At regional and national scales, hundreds of thousands of beehives are moved for pollination and honey production. In the United States, over half of all honeybee colonies are rented annually for almond pollination in California. This mass transport and mixing of bees is likely to be a major contributor to parasite transmission. Transmission reduction at such spatial scales is a matter for policy-level regulation, as has recently been called for by the IPBES pollinator report ${ }^{186}$, though with a focus on limiting spread of new disease agents rather than a focus on virulence evolution.

Improving disease treatments. Improved disease treatments are a longstanding desire of beekeepers ${ }^{187}$, but disease evolution theory ${ }^{162,163}$ and evidence from Marek's disease ${ }^{167}$ highlight that we should strive to develop treatments that provide complete parasite clearance, in contrast, for example, with most means of Varroa mite control which only reduce mite numbers in a colony. Such incomplete treatments-and similarly, management techniques that promote parasite tolerance over clearance-increase selection for parasite virulence ${ }^{164,165}$.

Using survivor stock. The idea behind survivor stock is to 'let nature takes its course' and allow sick colonies to die, thus propagating only surviving hosts. It constitutes the flip side of the coin from virulence reduction: increasing host resistance. Keeping susceptible bees alive through multiple interventions-the approach typically taken in beekeeping-dilutes natural selection for disease 
resistance. In contrast, allowing disease survivors to propagate and (importantly) allowing nonresistant colonies to perish could lead to more resistant bees with fewer disease problems. Keeping the sickest bees alive has the same effect as a leaky vaccine or high disease tolerance: it reduces the cost of virulence, and as such may lead to the evolution of more virulent parasites. In the case of the parasitic Varroa mite, there is evidence that a survivor stock approach has succeeded in producing bee stocks that do not require routine intervening treatments ${ }^{188,189}$. There are, however, short-term risks with this approach that should be anticipated: dying colonies often have high drifting rates, potentially increasing parasite transmission between colonies ${ }^{62}$.

Increasing genotypic diversity. Increasing genotypic diversity is another tactic for improving disease resistance. In most other agricultural contexts, greater genotypic diversity may save some individuals in a flock, herd, or field. But in honeybees, the colony is the unit of selection, and greater within-colony genotypic diversity-due to polyandry (multiple mating) in honeybee queens-bolsters individual colonies. Colonies from queens with higher mating number have greater disease resistance and overall survivorship ${ }^{70-72,190}$. Genotypic diversity can be considered at scales beyond the colony. For example, the survivor stock approach discussed above may encourage disease resistance diversity at a landscape scale, assuming the presence of a variety of resistance alleles in breeding populations.

Managed honeybees have been bred to express resistance traits. Chief among these are Varroa-sensitive hygiene, the phenotype by which nurse bees detect Varroa-infested brood and remove them from the colony ${ }^{191,192}$ and auto- or allo-grooming in which workers remove mites off their own or nestmates' bodies ${ }^{193}$. A key challenge is that trait-breeding approaches operate in apparent tension with the simultaneous pursuit of within-colony diversity. Classical animal breeding, including in honeybees, is based on reducing overall genotypic diversity (for example, through back-crosses or closed populations) in order to increase incidence of targeted alleles $^{194,195}$. Maintaining such alleles in managed bees is difficult given large dispersal distances of drones ${ }^{196}$, queen multiple mating, and high labour demands for maintaining inbred lines, all of which contribute to the relatively low adoption of Varroa-sensitive hygiene and other selected traits among beekeepers ${ }^{197}$. More work is needed to understand how: (1) genotypic diversity can be tractably maintained or increased by beekeepers operating in different management contexts; and (2) if and how genotypic diversity can be integrated into traditional breeding programs that have successfully identified resistance alleles.

Supporting behavioural resistance. It is critical that beekeepers support honeybee behavioural defence mechanisms and other forms of social immunity. This can be challenging when these mechanisms conflict with other beekeeping interests. One example is the longstanding bias in American beekeeping against propolis, which is known to increase colony-level resistance to several parasites ${ }^{198}$ but which also 'gums up' hives, making it difficult to open hives and separate hive components. Second, beekeepers routinely manage colonies to discourage reproductive swarming, but it is now known that swarming temporarily reduces both the adult bee population and available brood, thus negatively impacting tracheal mites ${ }^{199}$ and Varro $^{54}$. There are near-term evolutionary ramifications to these conflicts, and beekeepers may have selected for bees that are more convenient to manage but handicapped in behavioural defences. More work is needed to identify other behavioural and social immune pathways and integrate them into profitable beekeeping practices.

Increasing dietary diversity and flexibility. A related intervention is reducing honeybee dependency on processed sugars and instead providing them with a varied floral diet. In addition to optimizing individual bee health and immune function, plant diversity supports behavioural and social immune defences, for example by providing bees taxonomically rich sources of propolis ${ }^{85,198,200}$ and promoting production of hydrogen peroxide in honey ${ }^{79}$. In addition, certain bacteria in the honeybee gut microbiome help reduce disease burdens. Access to greater diversity of flowering plants allows honeybees to acquire or maintain such beneficial microorganisms ${ }^{115}$.

Management trade-offs. We cannot understate that all of these management suggestions are most difficult to implement in those systems that have the most to gain from them. Integrating these biology-based practices into commercial-scale migratory beekeeping requires translational research to identify specific actions that are practical and profitable. It will require the work of social scientists and educators to modify human behaviours. Change requires that management for disease be accomplished with actions that are affordable and economically and socially beneficial for beekeepers. Despite thin profit margins, we hope that the prospect for realized sustainability will be powerful motivation.

In addition, buttressing the health of managed pollinators must not be done at the expense of native pollinators, as honeybees can serve as reservoirs of diseases that threaten wild bees ${ }^{201-203}$ and other managed bees ${ }^{204}$. More than 20,000 species of wild bees play critical roles in agriculture and native ecosystems, and disease risk is a threat to this critical component of biodiversity ${ }^{10,186}$. Many of the disease management interventions we suggest could benefit native bees by reducing disease levels in honeybees, thus reducing the risk of spillover to other species. But others-such as providing honeybees access to diverse forage plants-could increase contact between species, thus increasing spillover risk. This may be especially true when forage plant density is low, thus forcing managed and wild bees to share plants more often. More research is needed to understand the risk of parasite spillover, as well as the full range of trade-offs associated with different honeybee disease management interventions.

\section{Outlook}

Although further research on honeybee disease ecology and evolution is critical for beekeeping and pollinator-dependent agriculture, such work can contribute to our understanding of disease ecology and evolution at fundamental levels, given several particulars of honeybee natural history. For example, honeybees are eusocial with a hierarchical population structure ${ }^{205}$, thus forming a system distinct from non-social organisms on which evolutionary and ecological pressures may operate distinctly. Second, honeybee colonies are found in varying densities and in both stationary and migratory populations, constituting an attractive model system for exploring the role of spatial structuring in virulence evolution.

Studying honeybee diseases comes with logistical challenges in terms of experimental design and execution. A key issue is replication, and for most applied disease studies, the unit of an independent sample is apiary-not colony-as apiary-level effects are well described in the beekeeping literature ${ }^{206}$. Managing apiaries that are separated in space, with sufficient numbers for adequate sample size, is expensive and represents a logistical challenge. Because of these challenges, most previous work in this realm has unfortunately not been replicated at the apiary level. Second, in most temperate climates honeybees have a distinct annual cycle that contributes variation to key colony parameters such as adult population size, brood production, and foraging. Studies focused on disease ecology and evolution must work within that annual cycle: if experimental manipulations fail once, they cannot be repeated until the following year. Third, honeybee colonies display variation even in closely related colonies within the same apiary, in terms of size, brood production, queen mating number, and temperament. Many of these parameters have direct bearing on responses to disease threats. Thus, it is critical that 
disease studies standardize both honeybee colonies and parasites as much as possible. For example, studies can start with replicated apiaries with nucleus colonies with the same hive body design and equivalent numbers of workers and new queens that are genetically related. Fourth, disease studies should inoculate colonies with carefully measured, identical infectious doses. As with apiary-level replication, most disease studies in honeybees do not meet these criteria. Given the need for such studies, we suggest that funding agencies recognize these unique and challenging design needs and consider increasing funding limits for honeybee disease research proposals.

\section{Conclusion}

Parasites form the greatest threat to the most economically important managed pollinator in the world. It is critical that we aim for health management practices that are rooted in the fundamental principles of evolution and ecology. To our minds, it is indefensible that current beekeeping practices are not only predicted to create more severe outbreaks, but to select for greater virulence. Developing new management systems that recognize ecological and evolutionary processes and constraints will take a global interdisciplinary effort uniting scientists from many fields with beekeepers and farmers. Such an effort must accommodate the challenging particularities of research on honeybees, but doing so will contribute to fundamental understanding of systems-level disease processes to the benefit of all. Such management systems must address other stressors, in particular pesticides and other agrochemicals known to negatively impact honeybees and wild bees ${ }^{18,207-210}$. Fully accounting for the evolutionary and ecological contexts of disease is a foundational step toward maintaining the agricultural productivity and security upon which a growing human population depends.

Received: 17 January 2017; Accepted: 20 June 2017;

Published online: 22 August 2017

\section{References}

1. Boecking, O. \& Genersch, E. Varroosis: the ongoing crisis in bee keeping. J. Consum. Protect. Food Safe. 3, 221-228 (2008).

2. Wenner, A. M. \& Bushing, W. W. Varroa mite spread in the United States. Bee Cult. 124, 342-343 (1996).

3. Martin, S. J. et al. Global honey bee viral landscape altered by a parasitic mite. Science 336, 1304-1306 (2012).

4. Pettis, J. S. \& Delaplane, K. S. Coordinated responses to honey bee decline in the USA. Apidologie 41, 256-263 (2010).

5. vanEngelsdorp, D. \& Meixner, M. D. A historical review of managed honey bee populations in Europe and the United States and the factors that may affect them. J. Invert. Pathol. 103, S80-S95 (2010).

6. Lee, K. V. et al. A national survey of managed honey bee 2013-2014 annual colony losses in the USA. Apidologie 46, 292-305 (2015).

7. Budge, G. E. et al. Pathogens as predictors of honey bee colony strength in England and Wales. PLoS ONE 10, e0133228 (2015).

8. Potts, S. G. et al. Declines of managed honey bees and beekeepers in Europe. J. Apicult. Res. 49, 15-22 (2015).

9. Dedej, S. \& Delaplane, K. S. Honey bee (Hymenoptera: apidae) pollination of rabbiteye blueberry Vaccinium ashei var. 'Climax' is pollinator density-dependent. J. Econ. Entomol. 96, 1215-1220 (2003).

10. Potts, S. G. et al. Global pollinator declines: trends, impacts and drivers. Trends Ecol. Evol. 25, 345-353 (2010).

11. Smith, M. R., Singh, G. M., Arian, D. M. \& Myers, S. S. Effects of decreases of animal pollinators on human nutrition and global health: a modelling analysis. Lancet 386, 1964-1972 (2015).

12. Gallai, N., Salles, J.-M., Settele, J. \& Vaissiere, B. E. Economic valuation of the vulnerability of world agriculture confronted with pollinator decline. Ecol. Econ. 68, 810-821 (2009).

13. Morse, R. A. \& Calderone, N. W. The value of honey bees as pollinators of U. S. crops in 2000. Bee Cult. 128, 1 (2000)

14. Williams, I. H. in Agricultural Zoology Reviews Vol. 6 (ed. Evans, K.) 229-257 (Intercept, Newcastle upon Tyne, 1994).

15. Klein, A.-M. et al. Importance of pollinators in changing landscapes for world crops. Proc. R. Soc. B 274, 303-313 (2007).

16. Chaplin-Kramer, R. et al. Global malnutrition overlaps with pollinator-dependent micronutrient production. Proc. R. Soc. B 281, 20141799 (2014)
17. Ellis, A. M., Myers, S. S. \& Ricketts, T. H. Do pollinators contribute to nutritional health? PLOS ONE 10, e114805 (2015).

18. Goulson, D., Nicholls, E., Botias, C. \& Rotheray, E. L. Bee declines driven by combined stress from parasites, pesticides, and lack of flowers. Science 347, 1255957 (2015)

19. Otto, C. R., Roth, C. L., Carlson, B. L. \& Smart, M. D. Land-use change reduces habitat suitability for supporting managed honey bee colonies in the Northern Great Plains. Proc. Natl Acad. Sci. USA 113, 10430-10435 (2016).

20. Core, A. et al. A new threat to honey bees, the parasitic phorid fly Apocephalus borealis. PLoS ONE 7, e29639 (2012).

21. Higes, M., Martín-Hernández, R. \& Meana, A. Nosema ceranae in Europe: an emergent type C nosemosis. Apidologie 41, 375-392 (2010).

22. Sammataro, D., de Guzman, L., George, S., Ochoa, R. \& Otis, G. Standard methods for tracheal mite research. J. Apicult. Res. http://dx.doi. org/10.3896/IBRA.1.52.4.20 (2013).

23. Tarpy, D. R. \& Seeley, T. D. Lower disease infections in honeybee (Apis mellifera) colonies headed by polyandrous vs monandrous queens. Naturwissenschaften 93, 195-199 (2006).

24. Carrillo-Tripp, J., Dolezal, A. G., Goblirsch, M. J., Miller, W. A., Toth, A. L. \& Bonning, B. C. In vivo and in vitro infection dynamics of honey bee viruses. Sci. Rep. 6, 22265 (2016).

25. Dainat, B., Evans, J. D., Chen, Y. P., Gauthier, L. \& Neumann, P. Dead or alive: Deformed Wing Virus and Varroa destructor reduce the life span of winter honeybees. Appl. Environ. Microbiol. 78, 981-987 (2012).

26. Nazzi, F. et al. Synergistic parasite-pathogen interactions mediated by host immunity can drive the collapse of honeybee colonies. PLoS Pathog. 8, e1002735 (2012).

27. vanEngelsdorp, D. et al. Colony Collapse Disorder: A descriptive study. PLoS ONE 4, e6481 (2009).

28. Le Conte, Y., Ellis, M. \& Ritter, W. Varroa mites and honey bee health: can Varroa explain part of the colony losses? Apidologie 41, 353-363 (2010).

29. Guzmán-Novoa, E. et al. Varroa destructor is the main culprit for the death and reduced populations of overwintered honey bee (Apis mellifera) colonies in Ontario, Canada. Apidologie 41, 443-450 (2010).

30. Kraus, B. \& Page, R. E. Effect of Varroa jacobsoni (Mesostigmata: Varroidae) on feral Apis mellifera (Hymenoptera: Apidae) in California. Environ. Entomol. 24, 1473-1480 (1995).

31. Kielmanowicz, M. G. et al. Prospective large-scale field study generates predictive model identifying major contributors to colony losses. PLoS Pathog. 11, e1004816 (2015).

32. Cox-Foster, D. L. et al. A metagenomic survey of microbes in honey bee colony collapse disorder. Science 318, 283-287 (2007).

33. Bromenshenk, J. J. et al. Iridovirus and microsporidian linked to honey bee colony decline. PLoS ONE 5, e13181 (2010).

34. Di Prisco, G. et al. Neonicotinoid clothianidin adversely affects insect immunity and promotes replication of a viral pathogen in honey bees. Proc. Natl Acad. Sci. USA 110, 18466-18471 (2013).

35. Alaux, C. et al. Interactions between Nosema microspores and a neonicotinoid weaken honeybees (Apis mellifera). Environ. Microbiol. 12, 774-782 (2010).

36. Mullin, C. A. et al. High levels of miticides and agrochemicals in North American apiaries: implications for honey bee health. PLOS ONE 5, e9754 (2010).

37. Berry, J. A., Hood, W. M., Pietravalle, S. \& Delaplane, K. S. Field-level sublethal effects of approved bee hive chemicals on honey bees (Apis mellifera L). PLoS ONE 8, e76536 (2013).

38. Kermack, W. O. \& McKendrick, A. G. A contribution to the mathematical theory of epidemics. Proc. R. Soc. Lon. Ser. A 115, 700-721 (1927).

39. Anderson, R. M. \& May, R. M. Infectious Diseases of Humans: Dynamics and Control (Oxford Univ. Press, Oxford, 1991).

40. Hudson, P. J., Rizzoli, A., Grenfell, B. T., Heesterbeek, H. \& Dobson, A. P. in The Ecology of Wildlife Diseases (eds Hudson, P. J. et al.) (Oxford Univ. Press, Oxford, 2002).

41. Pandey, A. et al. Strategies for containing Ebola in West Africa. Science 346, 991-995 (2014).

42. Keeling, M. J., Woolhouse, M. E. J., May, R. M., Davies, G. \& Grenfell, B. T. Modelling vaccination strategies against foot-and-mouth disease. Nature 421, 136-142 (2003).

43. Anderson, R. M., Jackson, H. C., May, R. M. \& Smith, A. M. Population dynamics of fox rabies in Europe. Nature 289, 765-771 (1981).

44. Lloyd-Smith, J. O. et al. Should we expect population thresholds for wildlife disease? Trends Ecol. Evol. 20, 511-519 (2005).

45. Peel, A. J. et al. The effect of seasonal birth pulses on pathogen persistence in wild mammal populations. Proc. R. Soc. B 281, 20132962 (2014).

46. Bartlett, M. S. Measles periodicity and community size. J. R. Stat. Soc. Ser. A 120, 48-70 (1957).

47. Bjørnstad, O. N., Finkenstädt, B. F. \& Grenfell, B. T. Dynamics of measles epidemics: estimating scaling of transmission rates using a Time series SIR model. Ecol. Monogr. 72, 169-184 (2002). 
48. Brown, C. R. \& Brown, M. B. Empirical measurement of parasite transmission between groups in a colonial bird. Ecology $\mathbf{8 5}$, 1619-1626 (2004).

49. Ramsey, D. et al. The effects of reducing population density on contact rates between brushtail possums: implications for transmission of bovine tuberculosis. J. Appl. Ecol. 39, 806-818 (2002).

50. Farrar, C. The influence of colony populations on honey production. J. Agricult. Res 54, 945-954 (1937).

51. Delaplane, K. S. Practical science-research helping beekeepers 2. Colony manipulations for honey production. Bee World 78, 5-11 (1997).

52. Seeley, T. \& Morse, R. The nest of the honey bee (Apis mellifera L.). Insectes Sociaux 23, 495-512 (1976).

53. Delaplane, K. S. \& Hood, W. M. Economic threshold for Varroa jacobsoni Oud. in the southeastern USA. Apidologie 30, 383-395 (1999).

54. Loftus, J. C., Smith, M. L. \& Seeley, T. D. How honey bee colonies survive in the wild: testing the importance of small nests and frequent swarming. PLoS ONE 11, e0150362 (2016).

55. Seeley, T. D. Honeybee Ecology (Princeton Univ. Press, Princeton, 1985).

56. Killion, E. E. Honey in the Comb (Dadant and Sons, Hamilton, IL, 1981).

57. Seeley, T. D., Tarpy, D. R., Griffin, S. R., Carcione, A. \& Delaney, D. A A survivor population of wild colonies of European honeybees in the northeastern United States: investigating its genetic structure. Apidologie 46, 654-666 (2015).

58. Seeley, T. D. \& Smith, M. L. Crowding honeybee colonies in apiaries can increase their vulnerability to the deadly ectoparasite Varroa destructor. Apidologie 46, 716-727 (2015).

59. Greatti, M., Milani, N. \& Nazzi, F. Reinfestation of an acaricide-treated apiary by Varroa jacobsoni Oud. Exp. Appl. Acarol. 16, 279-286 (1992).

60. Frey, E. \& Rosenkranz, P. Autumn invasion rates of Varroa destructor (Mesostigmata: Varroidae) into honey bee (Hymenoptera: Apidae) colonies and the resulting increase in mite populations. J. Econ. Entomol. 107, 508-515 (2014).

61. Nolan, M. P. \& Delaplane, K. S. Distance between honey bee Apis mellifera colonies regulates populations of Varroa destructor at a landscape scale. Apidologie 48, 8-16 (2016).

62. Frey, E., Schnell, H. \& Rosenkranz, P. Invasion of Varroa destructor mites into mite-free honey bee colonies under the controlled conditions of a military training area. J. Apicult. Res. 50, 138-144 (2011).

63. King, K. C. \& Lively, C. M. Does genetic diversity limit disease spread in natural host populations? Heredity 109, 199-203 (2012).

64. Keesing, F. et al. Impacts of biodiversity on the emergence and transmission of infectious diseases. Nature 468, 647-652 (2010).

65. Civitello, D. J. et al. Biodiversity inhibits parasites: Broad evidence for the dilution effect. Proc. Natl Acad. Sci. USA 112, 8667-8671 (2015).

66. Zhu, Y. Y. et al. Genetic diversity and disease control in rice. Nature 406, 718-722 (2000).

67. Mundt, C. C. Use of multiline cultivars and cultivar mixtures for disease management. Annu. Rev. Phytopathol. 40, 381-410 (2002).

68. Schmid-Hempel, P. Parasites in Social Insects (Princeton Univ. Press, Princeton, 1998).

69. Tarpy, D., Nielsen, R. \& Nielsen, D. A scientific note on the revised estimates of effective paternity frequency in Apis. Insectes Sociaux 51, 203-204 (2004).

70. Seeley, T. D. \& Tarpy, D. R. Queen promiscuity lowers disease within honeybee colonies. Proc. R. Soc. B 274, 67-72 (2007).

71. Tarpy, D. R. Genetic diversity within honeybee colonies prevents severe infections and promotes colony growth. Proc. R. Soc. B 270, 99-103 (2003).

72. Delaplane, K. S., Pietravalle, S., Brown, M. A. \& Budge, G. E. Honey bee colonies headed by hyperpolyandrous queens have improved brood rearing efficiency and lower infestation rates of parasitic Varroa mites. PLOS ONE 10, e0142985 (2015).

73. Lochmiller, R. L. \& Deerenberg, C. Trade-offs in evolutionary immunology: just what is the cost of immunity? Oikos 88, 87-98 (2000).

74. Ayres, J. S. \& Schneider, D. S. The role of anorexia in resistance and tolerance to infections in Drosophila. PLoS Biol. 7, e1000150 (2009).

75. Moret, Y. \& Schmid-Hempel, P. Survival for immunity: the price of immune system activation for bumblebee workers. Science 290, 1166-1168 (2000).

76. Siva-Jothy, M. T. \& Thompson, J. J. W. Short-term nutrient deprivation affects immune function. Physiol. Entomol. 27, 206-212 (2002).

77. vanEngelsdorp, D., Hayes, J., Underwood, R. M., Pettis, J. \& Gay, N. A survey of honey bee colony losses in the U. S., fall 2007 to spring 2008. PLOS ONE 3, e4071 (2008).

78. DeGrandi-Hoffman, G. et al. Honey bee colonies provided with natural forage have lower pathogen loads and higher overwinter survival than those fed protein supplements. Apidologie 47, 186-196 (2016).

79. Alaux, C., Ducloz, F., Crauser, D. \& Le Conte, Y. Diet effects on honeybee immunocompetence. Biol. Lett. 6, 562-565 (2010).

80. de Roode, J. C., Lefèvre, T. \& Hunter, M. D. Self-medication in animals. Science 340, 150-151 (2013).
81. Villalba, J. J., Miller, J., Ungar, E. D., Landau, S. Y. \& Glendinning, J. Ruminant self-medication against gastrointestinal nematodes: evidence, mechanism, and origins. Parasite 21, 31 (2014).

82. de Roode, J. C. \& Lefèvre, T. Behavioral immunity in insects. Insects 3, 789-820 (2012).

83. Gherman, B. I. et al. Pathogen-associated self-medication behavior in the honeybee Apis mellifera. Behav. Ecol. Sociobiol. 68, 1777-1784 (2014).

84. Castella, G., Chapuisat, M. \& Christe, P. Prophylaxis with resin in wood ants. Anim. Behav. 75, 1591-1596 (2008).

85. Simone-Finstrom, M. D. \& Spivak, M. Increased resin collection after parasite challenge: a case of self-medication in honey bees? PLOS ONE 7, e34601 (2012).

86. Cremer, S., Armitage, S. A. O. \& Schmid-Hempel, P. Social immunity. Curr. Biol. 17, R693-R702 (2007).

87. López, J. H., Schuehly, W., Crailsheim, K. \& Riessberger-Gallé, U. Trans-generational immune priming in honeybees. Proc. R. Soc. B. 281, 20140454 (2014).

88. Byrd, A. L. \& Segre, J. A. Adapting Koch's postulates. Science 351, 224-226 (2016).

89. Johnson, P. T. J., de Roode, J. C. \& Fenton, A. Why infectious disease research needs community ecology. Science 349, 1259504 (2015).

90. Alizon, S., de Roode, J. C. \& Michalakis, Y. Multiple infections and the evolution of virulence. Ecol. Lett. 16, 556-567 (2013).

91. Pedersen, A. B. \& Fenton, A. Emphasizing the ecology in parasite community ecology. Trends Ecol. Evol. 22, 133-139 (2007).

92. May, R. M. \& Nowak, M. A. Coinfection and the evolution of parasite virulence. Proc. R. Soc. B 261, 209-215 (1995).

93. Van Baalen, M. \& Sabelis, M. W. The dynamics of multiple infection and the evolution of virulence. Am. Nat. 146, 881-910 (1995)

94. Nowak, M. A. \& May, R. M. Superinfection and the evolution of parasite virulence. Proc. R. Soc. B 255, 81-89 (1994).

95. Blackwell, A. D., Martin, M., Kaplan, H. \& Gurven, M. Antagonism between two intestinal parasites in humans: the importance of co-infection for infection risk and recovery dynamics. Proc. R. Soc. B 280, 20131671 (2013).

96. Knowles, S. C. L. et al. Stability of within-host-parasite communities in a wild mammal system. Proc. R. Soc. B 280, 20130598 (2013).

97. Ezenwa, V. O. \& Jolles, A. E. Opposite effects of anthelmintic treatment on microbial infection at individual versus population scales. Science $\mathbf{3 4 7}$, 175-177 (2015)

98. Jolles, A. E., Ezenwa, V. O., Etienne, R. S., Turner, W. C. \& Olff, H. Interactions between macroparasites and microparasites drive infection patterns in free-ranging African buffalo. Ecology 89, 2239-2250 (2008).

99. Anderson, D. L. \& Gibbs, A. J. Inapparent virus infections and their interactions in pupae of the honey bee (Apis mellifera Linnaeus) in Australia. J. Gen. Virol. 69, 1617-1625 (1988).

100. Toplak, I., Jamnikar Ciglenečki, U., Aronstein, K. \& Gregorc, A. Chronic bee paralysis virus and Nosema ceranae experimental co-infection of winter honey bee workers (Apis mellifera L.). Viruses 5, 2282-2297 (2013).

101. Antúnez, K. et al. Immune suppression in the honey bee (Apis mellifera) following infection by Nosema ceranae (Microsporidia). Environ. Microbiol. 11, 2284-2290 (2009).

102. Chen, Y. P. et al. Multiple virus infections in the honey bee and genome divergence of honey bee viruses. J. Invert. Pathol. 87, 84-93 (2004).

103. Delaplane, K. S., Ellis, J. D. \& Hood, W. M. A test for interactions between Varroa destructor (Acari: Varroidae) and Aethina tumida (Coleoptera: Nitidulidae) in colonies of honey bees (Hymenoptera: Apidae). Ann. Entomol. Soc. Am. 103, 711-715 (2010).

104. Downey, D. L. \& Winston, M. L. Honey bee colony mortality and productivity with single and dual infestations of parasitic mite species. Apidologie 32, 567-575 (2001).

105. Cornman, R. S. et al. Pathogen webs in collapsing honey bee colonies. PLoS ONE 7, 15 (2012).

106. Ellis, J. D., Evans, J. D. \& Pettis, J. Colony losses, managed colony population decline, and Colony Collapse Disorder in the United States. J. Apicult. Res. 49, 134-136 (2010).

107. Mondet, F., de Miranda, J. R., Kretzschmar, A., Le Conte, Y. \& Mercer, A $\mathrm{R}$. On the front line: quantitative virus dynamics in honeybee (Apis mellifera L.) colonies along a new expansion front of the parasite Varroa destructor. PLoS Pathog. 10, e1004323 (2014).

108. Wilfert, L. et al. Deformed wing virus is a recent global epidemic in honeybees driven by Varroa mites. Science 351, 594-597 (2016).

109. Yang, X. L. \& Cox-Foster, D. L. Impact of an ectoparasite on the immunity and pathology of an invertebrate: Evidence for host immunosuppression and viral amplification. Proc. Natl Acad. Sci. USA 102, 7470-7475 (2005).

110. Oliver, K. M., Russell, J. A., Moran, N. A. \& Hunter, M. S. Facultative bacterial symbionts in aphids confer resistance to parasitic wasps. Proc. Natl Acad. Sci. USA 100, 1803-1807 (2003). 
111. Gerardo, N. M. \& Parker, B. J. Mechanisms of symbiont-conferred protection against natural enemies: an ecological and evolutionary framework. Curr. Opin. Insect Sci. 4, 8-14 (2014).

112. Buffie, C. G. \& Pamer, E. G. Microbiota-mediated colonization resistance against intestinal pathogens. Nat. Rev. Immunol. 13, 790-801 (2013).

113. Moran, N. A. Genomics of the honey bee microbiome. Curr. Opin. Insect Sci. 10, 22-28 (2015).

114. Omar, M. O. M. et al. Antagonistic effect of gut bacteria in the hybrid carniolan honey bee, Apis mellifera carnica, against Ascosphaera apis, the causal organsim of chalkbrood disease. J. Apicult. Sci. 58, 17-27 (2014).

115. Corby-Harris, V. et al. Parasaccharibacter apium, gen. nov., sp nov., improves honey bee (Hymenoptera: Apidae) resistance to Nosema. J. Econ. Entomol. 109, 537-543 (2016).

116. Burnet, M. \& White, D. O. The Natural History of Infectious Disease (Cambridge Univ. Press, Cambridge, 1972).

117. Anderson, R. M. \& May, R. M. Coevolution of hosts and parasites. Parasitology 85, 411-426 (1982).

118. Bremermann, H. J. \& Thieme, H. R. A competitive exclusion principle for pathogen virulence. J. Math. Biol. 27, 179-190 (1989).

119. May, R. M. \& Anderson, R. M. Epidemiology and genetics in the coevolution of parasites and hosts. Proc. R. Soc. B 219, 281-313 (1983).

120. Levin, S. \& Pimentel, D. Selection of intermediate rates of increase in parasite-host systems. Am. Nat. 117, 308-315 (1981).

121. Bremermann, H. J. \& Pickering, J. A game-theoretical model of parasite virulence. J. Theor. Biol. 100, 411-426 (1983).

122. Frank, S. A. Models of parasite virulence. Quart. Rev. Biol. 71, 37-78 (1996).

123. Antia, R., Levin, B. R. \& May, R. M. Within-host population dynamics and the evolution and maintenance of microparasite virulence. Am. Nat. 144, 457-472 (1994).

124. Sasaki, A. \& Iwasa, Y. Optimal growth schedule of pathogens within a host: switching between lytic and latent cycles. Theor. Pop. Biol. 39, 201-239 (1991).

125. Alizon, S., Hurford, A., Mideo, N. \& Van Baalen, M. Virulence evolution and the trade-off hypothesis: history, current state of affairs and the future. J. Evol. Biol. 22, 245-259 (2009).

126. de Roode, J. C., Yates, A. J. \& Altizer, S. Virulence-transmission trade-offs and population divergence in virulence in a naturally occurring butterfly parasite. Proc. Natl Acad. Sci. USA 105, 7489-7494 (2008).

127. Bolker, B. M., Nanda, A. \& Shah, D. Transient virulence of emerging pathogens. J. R. Soc. Lon. Interf. 7, 811-822 (2010).

128. Jensen, K. H., Little, T. J., Skorping, A. \& Ebert, D. Empirical support for optimal virulence in a castrating parasite. PLoS Biol. 4, e197 (2006).

129. Mackinnon, M. J. \& Read, A. F. Genetic relationships between parasite virulence and transmission in the rodent malaria Plasmodium chabaudi. Evolution 53, 689-703 (1999).

130. Messenger, S. L., Molineux, I. J. \& Bull, J. J. Virulence evolution in a virus obeys a trade-off. Proc. R. Soc. B 266, 397-404 (1999).

131. Fraser, C., Hollingsworth, T. D., Chapman, R., de Wolf, F. \& Hanage, W. P. Variation in HIV-1 set-point viral load: Epidemiological analysis and an evolutionary hypothesis. Proc. Natl Acad. Sci. USA 104, 17441-17446 (2007).

132. Mackinnon, M. J. \& Read, A. F. Virulence in malaria: an evolutionary viewpoint. Philos. Trans. R. Soc. Lon. Ser. B 359, 965-986 (2004).

133. Bull, J. J., Molineux, I. J. \& Rice, W. R. Selection of benevolence in a host-parasite system. Evolution 45, 875-882 (1991).

134. Ewald, P. W. Host-parasite relations, vectors, and the evolution of disease severity. Annu. Rev. Ecol. System 14, 465-485 (1983).

135. de Roode, J. C. et al. Virulence and competitive ability in genetically diverse malaria infections. Proc. Natl Acad. Sci. USA 102, 7624-7628 (2005).

136. Vojvodic, S., Jensen, A. B., Markussen, B., Eilenberg, J. \& Boomsma, J. J. Genetic variation in virulence among chalkbrood strains infecting honeybees. PLOS ONE 6, e25035 (2011).

137. McMahon, D. P. et al. Elevated virulence of an emerging viral genotype as a driver of honeybee loss. Proc. R. Soc. B 283, 20160811 (2016).

138. Anderson, D. L. Variation in the parasitic bee mite Varroa jacobsoni Oud. Apidologie 31, 281-292 (2000).

139. Corrêa-Marques, M. H., Medina, L. M., Martin, S. J. \& De Jong, D. Comparing data on the reproduction of Varroa destructor. Genet. Mol. Res. 2, 1-6 (2003)

140. De Jong, D. \& Soares, A. E. E. An isolated population of Italian bees that has survived Varroa jacobsoni infestation without treatment for over 12 years. Am. Bee J. 137, 742-745 (1997).

141. Corrêa-Marques, M. H., de Jong, D., Rosenkranz, P. \& Gonçalves, L. S. Varroa-tolerant Italian honey bees introduced from Brazil were not more efficient in defending themselves against the mite Varroa destructor than Carniolan bees in Germany. Genet. Mol. Res. 1, 153-158 (2002).

142. Ritter, W., Leclercq, E. \& Koch, W. Observations on bee and Varroa mite populations in infested honey bee colonies. Apidologie 15, 389-399 (1984)
143. Martin, S. J. The role of Varroa and viral pathogens in the collapse of honeybee colonies: a modelling approach. J. Appl. Ecol. 38, 1082-1093 (2001).

144. Fries, I. \& Camazine, S. Implications of horizontal and vertical pathogen transmission for honey bee epidemiology. Apidologie 32, 199-214 (2001)

145. Haraguchi, Y. \& Sasaki, A. The evolution of parasite virulence and transmission rate in a spatially structured population. J. Theoret. Biol. 203, 85-96 (2000).

146. Best, A., Webb, S., White, A. \& Boots, M. Host resistance and coevolution in spatially structured populations. Proc. R. Soc. B 278, 2216-2222 (2011)

147. Van Baalen, M. in Adaptive Dynamics of Infectious Diseases: In Pursuit of Virulence Management (eds Dieckmann, U., Metz, J. A. J., Sabelis, M. W. \& Sigmund, K.) 85-103 (Cambridge Univ. Press, Cambridge, 2002).

148. Kamo, M., Sasaki, A. \& Boots, M. The role of trade-off shapes in the evolution of parasites in spatial host populations: An approximate analytical approach. J. Theoret. Biol. 244, 588-596 (2007)

149. O'Keefe, K. J. \& Antonovics, J. Playing by different rules: the evolution of virulence in sterilizing pathogens. Am. Nat. 159, 597-605 (2002).

150. Boots, M. \& Sasaki, A. 'Small worlds' and the evolution of virulence: infection occurs locally and at a distance. Proc. R. Soc. B 266, 1933-1938 (1999)

151. Lion, S. \& Boots, M. Are parasites "prudent" in space? Ecol. Lett. 13, 1245-1255 (2010)

152. Wild, G., Gardner, A. \& West, S. A. Adaptation and the evolution of parasite virulence in a connected world. Nature 459, 983-986 (2009).

153. Lion, S. \& van Baalen, M. Self-structuring in spatial evolutionary ecology. Ecol. Lett. 11, 277-295 (2008).

154. Rosenkranz, P. Honey bee (Apis mellifera L.) tolerance to Varroa jacobsoni Oud. in South America. Apidologie 30, 159-172 (1999).

155. Dahle, B. The role of Varroa destructor for honey bee colony losses in Norway. J. Apicult. Res. 49, 124-125 (2010).

156. Seeley, T. D. Honey bees of the Arnot Forest: a population of feral colonies persisting with Varroa destructor in the northeastern United States. Apidologie 38, 19-29 (2007).

157. Fleming-Davies, A. E., Dukic, V., Andreasen, V. \& Dwyer, G. Effects of host heterogeneity on pathogen diversity and evolution. Ecol. Lett. 18, 1252-1261 (2015).

158. Regoes, R. R., Nowak, M. A. \& Bonhoeffer, S. Evolution of virulence in a heterogeneous host population. Evolution 54, 64-71 (2000).

159. Kennedy, D. A. et al. Potential drivers of virulence evolution in aquaculture. Evol. Appl. 9, 344-354 (2016).

160. Kirchner, J. W. \& Roy, B. A. Evolutionary implications of host-pathogen specificity: fitness consequences of pathogen virulence traits. Evol. Ecol. Res. 4, 27-48 (2002)

161. Gandon, S. \& Michalakis, Y. Evolution of parasite virulence against qualitative or quantitative host resistance. Proc. R. Soc. B 267, 985-990 (2000).

162. Gandon, S., Mackinnon, M. J., Nee, S. \& Read, A. F. Imperfect vaccines and the evolution of pathogen virulence. Nature 414, 751-756 (2001)

163. de Roode, J. C., Lopez Fernandez de Castillejo, C., Faits, T. \& Alizon, S. Virulence evolution in response to anti-infection resistance: toxic food plants can select for virulent parasites of monarch butterflies. J. Evol. Biol. 24, 712-722 (2011).

164. Miller, M. R., White, A. \& Boots, M. The evolution of parasites in response to tolerance in their hosts: The good, the bad, and apparent commensalism. Evolution 60, 945-956 (2006).

165. Restif, O. \& Koella, J. C. Shared control of epidemiological traits in a coevolutionary model of host-parasite interactions. Am. Nat. 161, 827-836 (2003).

166. Atkins, K. E. et al. Vaccination and reduced cohort duration can drive virulence evolution: Marek's disease virus and industrialized agriculture. Evolution 67, 851-860 (2013).

167. Read, A. F. et al. Imperfect vaccination can enhance the transmission of highly virulent pathogens. PLoS Biol. 13, e1002198 (2015).

168. Oldroyd, B. P. Coevolution while you wait: Varroa jacobsoni, a new parasite of western honeybees. Trends Ecol. Evol. 14, 312-315 (1999).

169. Klee, J. et al. Widespread dispersal of the microsporidian Nosema ceranae, an emergent pathogen of the western honey bee, Apis mellifera. J. Invert. Pathol. 96, 1-10 (2007).

170. Daszak, P., Cunningham, A. A. \& Hyatt, A. D. Emerging infectious diseases of wildlife: threats to biodiversity and human health. Science 287, 443-449 (2000)

171. Lenski, R. E. \& May, R. M. The evolution of virulence in parasites and pathogens: reconciliation between two competing hypotheses. J. Theoret. Biol. 169, 253-265 (1994).

172. Griette, Q., Raoul, G. \& Gandon, S. Virulence evolution at the front line of spreading epidemics. Evolution 69, 2810-2819 (2015).

173. Berngruber, T. W., Froissart, R., Choisy, M. \& Gandon, S. Evolution of virulence in emerging epidemics. PLoS Pathog. 9, 8 (2013).

174. André, J. B. \& Hochberg, M. E. Virulence evolution in emerging infectious diseases. Evolution 59, 1406-1412 (2005). 
175. Hawley, D. M. et al. Parallel patterns of increased virulence in a recently emerged wildlife pathogen. PLoS Biol. 11, 11 (2013).

176. Sternberg, E. D., Li, H., Wang, R., Gowler, C. \& de Roode, J. C. Patterns of host-parasite adaptation in three populations of monarch butterflies infected with a naturally occurring protozoan disease: virulence, resistance, and tolerance. Am. Nat. 182, E235-E248 (2013).

177. Best, A., White, A. \& Boots, M. The implications of coevolutionary dynamics to host-parasite interactions. Am. Nat. 173, 779-791 (2009).

178. Boecking, O. \& Ritter, W. Grooming and removal behavior of Apis mellifera intermissa in Tunisia against Varroa jacobsoni. J. Apicult. Res. 32, 127-134 (1993).

179. Büchler, R. in New Perspectives on Varroa (ed. Matheson, A.) 12-23 (IBRA, 1994)

180. Rath, W. Co-adaptation of Apis cerana Fabr. and Varroa jacobsoni Oud. Apidologie 30, 97-110 (1999)

181. Higes, M., García-Palencia, P., Martín-Hernández, R. \& Meana, A. Experimental infection of Apis mellifera honeybees with Nosema ceranae (Microsporidia). J. Invert. Pathol. 94, 211-217 (2007).

182. Knell, R. J. Syphilis in Renaissance Europe: rapid evolution of an introduced sexually transmitted disease? Proc. R. Soc. B 271, S174-S176 (2004).

183. Dwyer, G., Levin, S. A. \& Buttel, L. A simulation model of the population dynamics and evolution of myxomatosis. Ecol. Monogr. 60, 423-447 (1990).

184. Tildesley, M. J., Bessell, P. R., Keeling, M. J. \& Woolhouse, M. E. J. The role of pre-emptive culling in the control of foot-and-mouth disease. Proc. $R$. Soc. B 276, 3239-3248 (2009).

185. Gilligan, C. A., Truscott, J. E. \& Stacey, A. J. Impact of scale on the effectiveness of disease control strategies for epidemics with cryptic infection in a dynamical landscape: an example for a crop disease. J. R. Soc. Interf. 4, 925-934 (2007).

186. Potts, S. G. et al. Summary for Policymakers of the Assessment Report of the Intergovernmental Science-Policy Platform on Biodiversity and Ecosystem Services on Pollinators, Pollination and Food Production. (IPBES, Bonn, 2016).

187. Danka, R. G., Rinderer, T. E., Spivak, M. \& Kefuss, J. Comments on: "Varroa destructor, research avenues towards sustainable control". J. Apicult. Res. 52, 69-71 (2013)

188. Fries, I., Imdorf, A. \& Rosenkranz, P. Survival of mite infested (Varroa destructor) honey bee (Apis mellifera) colonies in a Nordic climate. Apidologie 37, 564-570 (2006).

189. Le Conte, Y. et al. Honey bee colonies that have survived Varroa destructor. Apidologie 38, 566-572 (2007).

190. Mattila, H. R. \& Seeley, T. D. Genetic diversity in honey bee colonies enhances productivity and fitness. Science 317, 362-364 (2007).

191. Ibrahim, A. \& Spivak, M. The relationship between hygienic behavior and suppression of mite reproduction as honey bee (Apis mellifera) mechanisms of resistance to Varroa destructor. Apidologie 37, 31-40 (2006).

192. Ibrahim, A., Reuter, G. S. \& Spivak, M. Field trial of honey bee colonies bred for mechanisms of resistance against Varroa destructor. Apidologie 38, 67-76 (2007).

193. Guzman-Novoa, E., Emsen, B., Unger, P., Espinosa-Montaño, L. G. \& Petukhova, T. Genotypic variability and relationships between mite infestation levels, mite damage, grooming intensity, and removal of Varroa destructor mites in selected strains of worker honey bees (Apis mellifera L.). J. Invert. Pathol. 110, 314-320 (2012).

194. Page, R. E. Jr \& Laidlaw, H. H. Jr Closed population honeybee breeding. 2. Comparative methods of stock maintenance and selective breeding. J. Apicult. Res. 21, 38-44 (1982).

195. Rinderer, T. E. Bee Genetics and Breeding (Academic, London, 1986).

196. Ruttner, F. \& Ruttner, H. Untersuchungen über die Flugaktivität und das Paarungsverhalten der Drohnen. V. Drohensammelplätze und Paarungsdistanz. Apidologie 3, 203-232 (1972).

197. Status of Pollinators in North America (National Research Council, Washington DC, 2007).

198. Simone-Finstrom, M. \& Spivak, M. Propolis and bee health: the natural history and significance of resin use by honey bees. Apidologie 41, 295-311 (2010).

199. Royce, L. A., Rossignol, P. A., Burgett, D. M. \& Stringer, B. A. Reduction of tracheal mite parasitism of honey bees by swarming. Philos. Trans. R. Soc. Lon. Ser. B 331, 123-129 (1991).

200. Simone, M., Evans, J. D. \& Spivak, M. Resin collection and social immunity in honey bees. Evolution 63, 3016-3022 (2009).

201. Graystock, P., Goulson, D. \& Hughes, W. O. H. Parasites in bloom: flowers aid dispersal and transmission of pollinator parasites within and between bee species. Proc. R. Soc. B 282, 20151371 (2015).

202. Otterstatter, M. C. \& Thomson, J. D. Does pathogen spillover from commercially reared bumble bees threaten wild pollinators? PLOS ONE 3, e2771 (2008)
203. Fürst, M. A., McMahon, D. P., Osborne, J. L., Paxton, R. J. \& Brown, M. J. F. Disease associations between honeybees and bumblebees as a threat to wild pollinators. Nature 506, 364-366 (2014).

204. Gong, H. R. et al. Evidence of Apis cerana sacbrood virus infection in Apis mellifera. Appl. Environ. Microbiol. 82, 2256-2262 (2016).

205. Al-Khafaji, K., Tuljapurkar, S., Carey, J. R. \& Page, R. E. Hierarchical demography: a general approach with an application to honey bees. Ecology 90, 556-566 (2009).

206. Smart, M., Pettis, J., Rice, N., Browning, Z. \& Spivak, M. Linking measures of colony and individual honey bee health to survival among apiaries exposed to varying agricultural land use. PLoS ONE 11, e0152685 (2016).

207. Johansen, C. A. Pesticides and pollinators. Annu. Rev. Entomol. 22, 177-192 (1977).

208. Desneux, N., Decourtye, A. \& Delpuech, J.-M. The sublethal effects of pesticides on beneficial arthropods. Annu. Rev. Entomol. 52, 81-106 (2007).

209. Rundlöf, M. et al. Seed coating with a neonicotinoid insecticide negatively affects wild bees. Nature 521 (2015).

210. Stanley, D. A. et al. Neonicotinoid pesticide exposure impairs crop pollination services provided by bumblebees. Nature 528, 548-550 (2015).

211. Seitz, N. et al. A national survey of managed honey bee 2014-2015 annual colony losses in the USA. J. Apicult. Res. 54, 292-304 (2016)

212. Rivers, T. M. Viruses and Koch's postulates. J. Bacteriol. 33, 1-12 (1937).

213. Otis, G. W. \& Scott-Dupree, C. D. Effects of Acarapis woodi on overwintered colonies of honey bees (Hymenoptera, Apidae) in New York. J. Econ. Entomol. 85, 40-46 (1992).

214. McMullan, J. B. \& Brown, M. J. F. A qualitative model of mortality in honey bee (Apis mellifera) colonies infested with tracheal mites (Acarapis woodi). Exp. Appl. Acarol. 47, 225-234 (2009).

215. Soroker, V. et al. Evaluation of colony losses in Israel in relation to the incidence of pathogens and pests. Apidologie 42, 192-199 (2011).

216. Higes, M. et al. How natural infection by Nosema ceranae causes honeybee colony collapse. Environ. Microbiol. 10, 2659-2669 (2008).

217. Paxton, R. J., Klee, J., Korpela, S. \& Fries, I. Nosema ceranae has infected Apis mellifera in Europe since at least 1998 and may be more virulent than Nosema apis. Apidologie 38, 558-565 (2007).

218. Klinger, E. G., Vojvodic, S., DeGrandi-Hoffman, G., Welker, D. L. \& James, R. R. Mixed infections reveal virulence differences between host-specific bee pathogens. J. Invert. Pathol 129, 28-35 (2015).

219. de Miranda, J. R., Cordoni, G. \& Budge, G. The Acute bee paralysis virus-Kashmir bee virus-Israeli acute paralysis virus complex. J. Invert. Pathol. 103, S30-S47 (2010).

220. Francis, R. M., Nielsen, S. L. \& Kryger, P. Varroa-virus interaction in collapsing honey bee colonies. PLoS ONE 8, e57540 (2013).

221. Retschnig, G. et al. Sex-specific differences in pathogen susceptibility in honey bees (Apis mellifera). PLoS ONE 9, e85261 (2014).

222. Bailey, L., Gibbs, A. J. \& Woods, R. D. Sacbrood virus of the larval honey bee (Apis mellifera Linnaeus). Virology 23, 425-429 (1964).

223. Tokarz, R., Firth, C., Street, C., Cox-Foster, D. L. \& Lipkin, W. I. Lack of evidence for an association between Iridovirus and Colony Collapse Disorder. PLoS ONE 6, e21844 (2011).

224. Neumann, P. \& Elzen, P. The biology of the small hive beetle (Aethina tumida, Coleoptera: Nitidulidae): gaps in our knowledge of an invasive species. Apidologie 35, 229-247 (2004).

225. Anderson, R. M. \& May, R. M. Population biology of infectious diseases: Part I. Nature 280, 361-367 (1979).

226. Mideo, N., Alizon, S. \& Day, T. Linking within- and between-host dynamics in the evolutionary epidemiology of infectious diseases. Trends Ecol. Evol. 23, 511-517 (2008).

\section{Acknowledgements}

This work was supported by the National Institute of General Medical Sciences of the National Institutes of Health under award number R01GM109501. The content is solely the responsibility of the authors and does not necessarily represent the official views of the National Institutes of Health.

\section{Competing interests}

The authors declare no competing financial interests.

\section{Additional information}

Reprints and permissions information is available at www.nature.com/reprints. Correspondence and requests for materials should be addressed to B.J.B. or J.C.d. Publisher's note: Springer Nature remains neutral with regard to jurisdictional claims in published maps and institutional affiliations. 